\title{
THE POLICE AND SUBSTANTIVE RULEMAKING: REGONCILING PRINCIPLE AND EXPEDIENCY
}

\author{
Ronald J. Allen†
}

$A$ strange philosophy of law enforcement has been expounded by [our] Police Chief ... . The Chief says his officers cannot enforce the letter of the law setting a curfew of 10:00 P.M. on city streets for children under seventeen who are not accompanied by a parent.

[The] Chief . . says he does not think the public would stand for strict enforcement of the letter of the law. The court, too, he feels, would take a dim view of overly strict enforcement.

Since when, we feel compelled to enquire, is it the function of the Police Chief to decide which laws can or cannot be enforced? By what authority does he claim the right to interpret what the "public" will or will not stand for in law enforcement? ${ }^{1}$

Until recently the police were often regarded as impartial, unbiased, nondiscriminating enforcers of the criminal law, possessing and exercising no discretion in the decision to invoke the criminal process when a violation of the criminal law is brought to their attention. This conception, known as the "myth of full enforcement," was thought to represent the appropriate role of police in our society: "The police, in our legal tradition, are essentially ministerial officers. To them have been delegated relatively few grants of discretionary power ...."2 Accordingly, it

$\dagger$ Assistant Professor of Law, Faculty of Law and Jurisprudence, State University of New York at Buffalo. B.S. 1970, Marshall University; J.D. 1973, University of Michigan.

I am indebted to my colleague, Professor Lee Albert, and to Professor Joseph Vining of the University of Michigan Law School, for their comments on portions of this Article. I am also indebted to Robert S. Burrick, a second-year law student, for his research assistance.

${ }^{1}$ B. Grossman, Police Command: Decisions and Discretion 95 (1975) (quoting Editorial, Shall Police Chiefs Decide Which Laws to Enforce?, Capital Times (Madison, Wis.), Sept. 6, 1961).

2 Parratt, How Effective is a Police Department?, 199 AnNals 153 (1938). 
has long been assumed that the "police will arrest all who violate the criminal law."3

This charming folklore of the policeman as an impartial ministerial officer who enforces the letter of the law against all known violators did not prove to be an accurate reflection of reality, ${ }^{4}$ and there has been a growing realization that the cop on the beat often exercises discretion ${ }^{5}$ in his decision to invoke or not to invoke the criminal process. ${ }^{6}$ As a result of this realization

${ }^{3}$ Remington \& Rosenblum, The Criminal Law and the Legislative Process, 1960 U. ILL. L.F. 481, 496. Professors Remington and Rosenblum do not accept the myth. In fact, their article is one of the earlier pieces arguing its inaccuracy.

4 The most important step in the development of this realization was the publication, sixteen years ago, of Professor Joseph Goldstein's well known article on police discretion. Goldstein, Police Discretion Not to Invoke the Criminal Process: Low-Visibility Decisions in the Administration of Criminal Justice, 69 YALE L.J. 543 (1960). He was not the first, however, to isolate the problem of discretionary enforcement. See, e.g., Hall, Police and Law in a Democratic Society, 28 IND. L.J. 133 (1953). The next most important step occurred seven years after the Goldstein article when the President's Commission on Law Enforcement and Administration of Justice noted and discussed the problems of police discretion in decisions to invoke the criminal process. See The President's Comm'n on Law Enforcement and Administration of Justice, The Challenge of Crime in a Free Society, 10-12, 103-06 (1967) [hereinafter cited as The Challenge of Crime in a Free Society]; The President's Comm'n on Law Enforcement and Administration of Justice, Task Force Report: The Police $13-41$ (1967) [hereinafter cited as TASK FORCE REPORT]. Since then, more and more attention has been paid to the issue. See authorities cited at notes 5-23 infra. It may be some small consolation to know that we are not the only ones who were beguiled by the myth of full enforcement. Apparently Canada has gone through a similar process in the creation and subsequent discrediting of the myth. See B. Grossman, supra note 1, at 84 .

5 The word "discretion" and the phrase "police discretion not to invoke the criminal process" refers, for purposes of this article, to the process by which a police officer decides not to arrest an offender or otherwise invoke the criminal process when the officer has probable cause to believe that the particular offender committed a particular offense. For other definitions of the word, see K. Davis, Discretionary Justice: A Preliminary Inquiry 4-5 (1969) [hereinafter cited as Discretronary Justice]; Pound, Discretion, Dispensation and Mitigation: The Problem of the Individual Special Case, 35 N.Y.U.L. REv. 925, 926 (1960).

Police discretion may arise in at least three different contexts. First, the police department or an individual officer may decide not to invoke the criminal process because the particular offender-for example, the mayor's son-has somehow been selected for special treatment. While such offender-based discretion is a serious problem, it is only tangential to this discussion. See notes 207-10 infra \& accompanying text. The police also may decide not to invoke the criminal process because the particular offense has been selected for non-enforcement in all cases. This article will be principally concerned with the wisdom and legality of such offense-based discretion. Finally, the police may exercise discretion not to invoke the criminal process because of special circumstances. For example, a police officer may decide that the legislature could not have intended the statute to apply in a particular situation, as when an arrest for disturbing the peace might cause a riot. See notes $218-222$ infra \& accompanying text.

${ }^{6}$ We are largely indebted to the American Bar Foundation's Survey of the Administration of Criminal Justice in the United States for dispelling many of the myths that surrounded the police and other institutions in our criminal justice system. For example, Professor Goldstein's article owes much to the work done for the Survey. Goldstein, 
that the police are not simply ministerial officers, we have been forced to face some very hard questions that have been ignored until recently. ${ }^{7}$ The most obvious of these questions is the propriety, both as a legal and as a policy matter, of the police exercising discretion in enforcing the criminal law. As might be expected, there is no consensus on the answer. Some think that the myth of full enforcement should reflect reality, even though it presently does not, and that the appropriate role of the police is to enforce to the best of their abilities whatever statutes are enacted by the legislature. ${ }^{8}$ Others believe that the exercise of discretion not to invoke the criminal process is inevitable and "that idealism or naivete or both must be present in king-size doses in order to sustain the position that the legislature can or should play an exclusive role in the molding of criminal law policy.""9

This dispute over the appropriate relationship of the police to the legislature is largely a function of a perceived divergence of theory and practice in the administration of criminal law. Those who feel that the police should not exercise discretion believe that the rule of law mandates that conclusion regardless of actual police practice on the streets. ${ }^{10}$ Others, however, are more impressed by the apparent inevitability of police discretion $^{11}$ and believe that theory ought to be conformed to reality. ${ }^{12}$ The latter individuals are concerned with controlling

supra note 4, at 554-80. See also W. LaFave, Arrest: The Decision to TAke a Suspect INTO Custody 61-164 (1965). The latter is one of the reports of the Survey's field work.

${ }^{7}$ As late as 1969 , one authority could say that " $[t]$ here has been little attention given to such obviously important issues as the relationship between legislation, administrative policymaking, and judicial review of administrative policy." F. REMINGTON, D. Newman, E. Kimball, M. Melli, \& H. Goldstein, Criminal Justice Administration: Materials and Cases 1191 (1969).

${ }^{8}$ Goldstein, supra note 4, at 586. Professor Goldstein realizes "that the exercise of discretion cannot be completely eliminated where human beings are involved. The frailties of human language and human perception will always admit of borderline cases ...."Id. See also notes 198-225 infra \& accompanying text.

${ }^{9}$ Remington \& Rosenblum, supra note 3, at 482 n.2.

${ }^{10}$ Hall, supra note 4 , is one of the best statements of this position. But see note 14 infra.

${ }^{11}$ Breitel, Controls in Criminal Law Enforcement, 27 U. CHI. L. REv. 427 (1960); Remington \& Rosenblum, supra note 3.

${ }^{12}$ See, e.g., American Bar Association Project on Standards for Criminal Justice: Standards Relating to the Urban Police Function 15, 18-19 (1972); Task FORCE REPORT, supra note 4, at 32; Breitel, supra note 11; Caplan, The Case for Rulemaking by Law Enforcement Agencies, 36 Law \& Contemp. Prob. 500 (1971); Goldstein, Police Policy Formulation: A Proposal for Improving Police Performance, $65 \mathrm{MrcH}$. L. REv. 1123 (1967); Igleburger \& Schubert, Policy Making for the Police, 58 A.B.A.J. 307 (1972); Remington \& Rosenblum, supra note 3 , at 483. 
discretion "so as to avoid the unequal, the arbitrary, the discriminatory and the oppressive." 13 As one observer noted, the relevant inquiry "is to try to find or invent better ways to control police discretion in determining whether and when to enforce particular law."14

An unmistakable trend has developed in these attempts "to devise procedures which will result in police officers employing norms acceptable to society, rather than their personal norms, in their exercise of discretion", ${ }^{15}$ criminal law theorists have become increasingly enchanted with the use of administrative rulemaking to limit and guide the exercise of discretion. ${ }^{16}$ The genesis of this development is largely attributable to The President's Commission on Law Enforcement and Administration of Justice, ${ }^{17}$ which gave national exposure to the idea of administrative rulemaking as a method of controlling police discretion. ${ }^{18}$ Since then the idea of administrative rulemaking has been heralded by numerous commentators as a cure for myriad ills. Some argue that rulemaking offers a viable alterna-

${ }^{13}$ Breitel, supra note 11 , at 427 .

${ }^{14} \mathrm{~K}$. Davis, Preface to Police Discretion at iii (1975). [hereinafter cited as Police DisCrEtION]. Those supporting this position do not reject the importance of the rule of law. Quite the contrary, their purpose is to eliminate, as far as possible, arbitrary police action in order to control and restrict the unfettered discretionary power they believe the police now exercise. The main point of contention is, therefore, whether the law requires that the police be denied the power not to invoke the criminal law, or whether the inevitability of discretion not to invoke should be recognized and the discretion structured to the extent possible.

${ }^{15}$ Goldstein, supra note 12 , at 1128 .

${ }^{16}$ For a thorough discussion of administrative rules and rulemaking, see $1 \mathrm{~K}$. Davrs, Administrative LAw Treatise $\$ \S 5.01-7.20$ (1958) [hereinafter cited as ADMINISTRATIVE LAw TREATISE]. The fascination with administrative rules and rulemaking is also evident in much of the scholarship dealing with other aspects of the criminal process. See, e.g., M. Frankel, Criminal Sentences: Law Without Order 118-24 (1973).

${ }^{17}$ See note 4 supra.

18 The Challenge of Crime in a Free Society, supra note 4, at 103-06; Task FORCE REPORT, supra note 4, at 13-41.

Professor Davis' DisCRetionary Justice: A PRELIMINARY InQuiRY, supra note 5 , is often regarded as the seminal piece on the utilization of administrative rulemaking to limit police discretion. In fact, the concept was first discussed in TASK FORCE REPORT, supra note 4 , albeit on a more primitive level Compare DisCRerionary JUSTICE, supra, at 52-161, with TASK FORCE REPORT, supra, at 13-41. Moreover, the need for administrative rulemaking procedures was suggested much earlier than even the Task Force Report. See, e.g., Breitel, supra note 11, at 435 ("The real answer is to adopt practical administrative means for directing discretion, preferably by shared controls, and by reviewing its exercise internally. The search must be for the means."); Remington \& Rosenblum, supra note 3 , at 499 ("[I]t would appear both necessary and feasible to develop through legislation an adequate set of principles and criteria which, while recognizing the necessity and desirability of administrative discretion, will also channel and control such discretion to insure a proper degree of responsibility."). 
tive to the exclusionary rule as a means of protecting procedural rights of the populace. ${ }^{19}$ Others suggest that rulemaking may be useful in developing guidelines to facilitate police work in sensitive areas such as the use of firearms, ${ }^{20}$ the appropriate police posture during times of civil unrest, ${ }^{21}$ and appropriate responses

${ }^{19}$ Mapp v. Ohio, 367 U.S. 643 (1961), justified the exclusionary rule on two grounds: deterrence of unlawful police activity, and the protection of the courts' integrity. The logic of the first point is clear-if the police know that illegally seized evidence cannot be used against the individual whose rights were not respected, then the police will be less likely to engage in such behavior. How well the logic of the matter reflects reality is a matter of much disagreement. Compare, e.g., Kamisar, Public Safety $v$. Individual Liberties: Some "Facts" and "Theories", 53 J. CRIM. L.C. \& P.S. 171 (1962) and Kamisar, Wolf and Lustig Ten Years Later: Illegal State Evidence in State and Federal Courts, 43 Minn. L. Rev. 1083 (1959), with Oaks, Studying the Exclusionary Rule in Search and Seizure, 37 U. CHI. L. REv. 665 (1970). Moreover, the deterrent effect of the exclusionary rule is questionable. See generally LaFave, Improving Police Performance Through the Exclusionary Rule (pts. 1, 2), 30 Mo. L. Rev. 391, 566 (1965). Many commentators have speculated whether police rules could do a better job of controlling police behavior. See, e.g., Amsterdam, The Supreme Court and the Rights of Suspects in Criminal Cases, 45 N.Y.U.L. Rev. 785 (1970); Goldstein, Trial Judges and the Police: Their Relationships in the Administration of Criminal Justice, 14 CRIME \& DEL. 14 (1968); Goldstein, supra note 12; LaFave \& Remington, Controlling the Police: The Judge's Role in Making and Reviewing Law Enforcement Decisions, 63 Mrch. L. Rev. 987 (1965); Quinn, The Effect of Police Rulemaking on the Scope of Fourth Amendment Rights, 52 J. URBAN L. 25 (1974); Wilson \& Alprin, Controlling Police Conduct: Alternatives to the Exclusionary Rule, 36 LAW \& Contemp. Prob. 488 (1971). But see, e.g., Dix, Undercover Investigations and Police Rulemaking, 53 TExAs L. Rev. 203 (1975); Schwartz, Stop and Frisk: A Case Study in Judicial Control of the Police, 58 J. Crim. L.C. \& P.S. 433, 499 (1967); Critique, On the Limitations of Empirical Evaluations of the Exclusionary Rule: A Critique of the Spiotto Research and United States v. Calandra, 69 Nw. U.L. Rev. 740, 794 (1974).

This potential use of rulemaking takes on added significance in light of the Supreme Court's apparent abandonment of Mapp's second justification for the exclusionary rule-protecting judicial integrity. Compare United States v. Calandra, 414 U.S. 338, 347-52 (1974) (Powell, J.), with id. at 355-67 (Brennan, J., dissenting). Furthermore, the federal courts are now limited in their ability to entertain collateral attacks on guilty verdicts on the basis of alleged Fourth Amendment violations. See, e.g., Stone v. Powell, 96 S. Ct. 3037 (1976).

In short, the exclusionary rule seems to be increasingly under attack, and even if Mapp and Weeks v. United States, 232 U.S. 383 (1914) (mandating the exclusionary rule in federal courts), are not overruled in the near future, see generally Bivens v. Six Unknown Named Agents, 403 U.S. 388, 411 (1971) (Burger, C.J., dissenting), they are very likely to be reduced considerably in scope. If so, then encouraging the police or legislatures to promulgate rules governing the interactions of the police with citizens assumes even greater importance, and I support the idea wholeheartedly. As an example of what could be done, see A.L.I., Model Code of Pre-Arraignment Procedure (1975). See generally Model Rules for Law Enforcement Officers: A Manual on Police Discretion (1974) [hereinafter cited as ManUal]; Geller, Enforcing the Fourth Amendment: The Exclusionary Rule and its Alternatives, 1975 WASH. L.Q. 621. This, of course, is quite a different matter from the propriety of police rulemaking with respect to the substantive criminal law.

${ }^{20}$ Comment, Kill or Be Killed?: Use of Deadly Force in the Riot Situation, 56 CaLif. L. REv. 829 (1968).

${ }^{21}$ Goldstein, Police Response to Urban Crisis, 28 PUв. Ad. Rev. 417 (1968). 
to domestic disturbances. ${ }^{22}$ Still others believe that rulemaking should be used to deal with the most intractable problem of all-selective enforcement of the substantive criminal law ${ }^{23}$-and suggest that the police should cut back, and in essence amend, overly broad and consequently unenforceable statutes to manageable size through the administrative rulemaking process. ${ }^{24}$

I have no quarrel with much of this, ${ }^{25}$ but I unequivocally reject the suggestion that the police should engage in rulemaking that directly affects the scope of the substantive criminal law. ${ }^{26}$ I do not think that the structure of our law permits the police to exercise this kind of authority. ${ }^{27}$ Perhaps more importantly, I am convinced that it would not be wise to accord the police this power, even if it were permissible to do so. This Article will examine the bases of these conclusions. ${ }^{28}$

${ }_{22}$ Parnas, Police Discretion and Diversion of Incidents of Intra-Family Violence, 36 LAw \& Contemp. Prob. 539 (1971); Parnas, The Police to the Domestic Disturbance, 1967 Wis. L. REv. 914.

${ }^{23}$ See, e.g., A.B.A. Standards Relating to the Urban Police Function, supra note 12, Standard 4.4(a); MaNual, supra note 19, at 176-83; National Advisory Commission on Criminal Justice Standards and Goals: Police 21-28 (1973); Police Discretion, supra note 14, at 98-110; TASK FORCE REPORT, supra note 4, at 32, 34; Davis, An Approach to Legal Control of the Police, 52 Texas L. Rev. 703 (1974); Remington, The Role of Police in a Democratic Society, 56 J. CRIM. L.C. \& P.S. 361 (1965).

${ }^{24}$ The most outspoken advocate of this position is Professor Kenneth Culp Davis. His recent monograph-Police Discretion, supra note 14-apparently was written largely to make the point that police can and should cut back unenforceable statutes to manageable size through rulemaking.

${ }^{25}$ See note 19 supra.

${ }^{26}$ I will use the phrase "substantive rulemaking" to refer to Davis' suggestion that the police should reduce the scope of the substantive criminal law through an administrative rulemaking process that would provide for the nonenforcement of selected penal laws. For example, a police department might promulgate a rule not to arrest for possession of less than an ounce of marijuana.

${ }^{27}$ This Article primarily deals with state law, which, of course, varies from jurisdiction to jurisdiction. I am able to deal with what might be called "general principles," without explicating the law of any particular jurisdiction, because of the startling unanimity among jurisdictions on the issues I will be discussing.

${ }^{28} \mathrm{In}$ isolating the issue of the appropriate relationship of the police to the legislator, I have not overlooked the fact that " $[t]$ he police are only one part of the criminal justice system; the criminal justice system is only one part of the government; and the government is only one part of society." TASK FORCE REPORT, supra note 4, at 1. See also Breitel, supra note 11, at 432. For an elaboration of this point, see R. Pound, CRIMINal. JUSTICE IN AMERICA 3-26 (1930). I realize that one's views on other aspects of the criminal justice system might affect how one views the propriety of police discretion. For example, if one were convinced that prosecutors exercised their discretion not to prosecute in a fair, humane, and evenhanded manner, then one might be more reluctant to countenance the exercise of discretion by the police. But for my purposes, these considerations are of little importance, for I do not think that police rulemaking on substantive issues can be justified under any circumstances. For discussions of prosecutorial discretion, see F. Miller, Prosecution: The Decision to Charge a Suspect With a 


\section{Before turning to the substance of the argument, however, I wish to stress that I am not directly concerned with the propriety}

Crime (1970); Abrams, Internal Policy: Guiding the Exercise of Prosecutorial Discretion, 19 U.C.L.A.L. Rev. 1 (1971); Amsterdam, The One-Sided Sword: Selective Prosecution in Federal Courts, 6 Rut.-CAm. L. Rev. 1 (1974); Cole, The Decision to Prosecute, 4 LAw \& Soc'y. Rev. 331 (1970); Givelber, The Application of Equal Protection Principles to Selective Enforcement of the Criminal Law, 1973 U. ILL. L.F. 88; Kaplan, The Prosecutorial Discretion-A Comment, 60 Nw. U.L. Rev. 174 (1965). A review of these authorities demonstrates that we have been very much less hesitant to acknowledge the propriety of prosecutorial discretion than to sanction police discretion. This well may be due to a belief that because of the difference in education and perceived competence, "the prosecutor is qualified to exercise discretion while the average police agency is not." W. LAFAvE, supra note 6, at 72-73. See generally Symposium: Prosecutorial Discretion, 13 AM. CRIM. L. Rev. 379 (1976). For a discussion of how difficult it is to eliminate prosecutorial discretion from a judicial system, see Church, Plea Bargains, Concessions and the Courts: Analysis of a Quasi-Experiment, 10 Law \& Soc'y Rev. 377 (1976).

Professor Davis has concluded that prosecutors should also engage in rulemaking: "Prosecutors ... should be required to make and to announce rules that will guide their choices, stating as far as practicable what will and what will not be prosecuted. ..." Discretionary Justice, supra note 5, at 225. See also Abrams, supra. The A.B.A. Project on Standards for Criminal Justice implements this suggestion. Standard 2.5 of The Standards Relating to the Prosecution Function (1971) reads in part: "Each prosecutor's office should develop a statement of . . general policies to guide the exercise of prosecutorial discretion. . . See also A.L.I., MOdez COdE of Pre-Arraignment Procedure § 350.3(2) (1975); National Advisory Comm'N on Criminal Justice Standards and Goals: Task Force on Courts, Standard 3.3 (1973).

Davis' argument is predicated largely upon his belief that "[o]penness is a natural enemy of arbitrariness, a natural ally in the fight against injustice." DisCRETIONARY Justice, supra note 5, at 226. He may be right that "open" decisionmaking will impede arbitrary decisions, but before prosecutorial rulemaking is embraced, one must examine the possibility of undesirable side effects. For example, Professor Davis' suggestion inadequately addresses the issue of how the prosecutors are going to find the time to draft rules. If it is true that plea bargaining is mainly a function of overwhelming caseloads, see, e.g., Heumann, $A$ Note on Plea Bargaining and Case Pressure, 9 Law \& Soc'Y REv. 515 (1975), then it would seem appropriate to ask what the costs would be if prosecutorial resources were diverted from prosecution to rule drafting. Moreover, "open rulemaking" may decrease the deterrent efficacy of the criminal law. If the prosecutor (or the police) announces that only those who exceed the speed limit by more than five miles an hour will be prosecuted, might not everyone exceed it by four miles an hour? See Caplan, supra note 12, at 509 n.20. See also F. Zimring \& G. Hawkins, DETERRENCE 298 (1973) ("[S]ome scholars have suggested that an uncertain sanction ... may be a better deterrent than a specifically defined punishment." (footnote omitted)). If a prosecutor breaks his own rule and prosecutes someone within the statute but excluded by the rule, should the rule constitute a valid defense against the criminal charge? See generally Caplan, supra note 12, at 511; McGowan, Rule-Making and the Police, 70 Mich. L. Rev. 659, 693 (1972); Note, Violations by Agencies of Their Own Regulations, 87 HARv. L. Rev. 629 (1974). If so, what effect would that have on the difficulty of prosecution? Would it be viewed as simply giving the "criminal" another loophole to escape or to minimize punishment? Furthermore, would prosecutorial rulemaking encourage dilatory tactics by defense counsel? If so, what would be the consequences? See generally Alschuler, The Prosecutor's Role in Plea Bargaining, 36 U. CHI. L. REv. 50, 56-7 (1968).

Let me emphasize that I am not arguing against Davis' proposal; I am merely trying to show that the issue is much more complex than Davis acknowledges. Moreover, I am not arguing that it would be improper for prosecutors to engage in this 
of the police exercising enforcement discretion per se. ${ }^{29}$ Rather, $I$ intend to demonstrate that one suggestion for controlling the exercise of that discretion-the use of rulemaking by the police to limit the scope of the substantive criminal law-is inconsistent with our theory of government regardless of the propriety of police discretion in general. Of course, the propriety of an activity and the means of controlling it are clearly related. As one commentator has asked, "what basis is there for rulemaking if there is no . . . authority for police discretion?"30 None, obviously, and on that assumption the rest of this Article would be superfluous. If, however, we are willing to countenance the exercise of discretion not to invoke the criminal process, explicitly or implicitly, that does not say anything at all about the nature of the beast ${ }^{31}$-it simply presupposes its existence. ${ }^{32}$ Bearing that in mind, I will now proceed to discuss the principles of law, and the wisdom they reflect, that I think relevant to the question at hand-the propriety of police rulemaking that directly affects the scope of the substantive criminal law.

\section{Substantive Rulemaking by the Police}

The proponents of substantive rulemaking are so impressed by its potential ${ }^{33}$ that one of them, Professor Gerald Caplan, could confidently assert that "the concept of rulemaking . . . is likely to remain free of the controversy that has inhibited earlier proposals for reform." ${ }^{34}$ Well, I hate to be the fly in the ointment, but in my opinion the concept of substantive rulemaking ought to be inhibited. The concept has remained relatively free from controversy so far because its proponents have not always recognized, or at least not discussed, the depth of the issues

type of rulemaking. The crucial distinction between prosecutorial rulemaking and police rulemaking on substantive issues is that we may have explicitly legitimized the former's exercise of discretion while we have, as I will show, emphatically rejected the latter's. See, e.g., 21 U.S.C. \$ 336 (1970). I should point out, however, that many of the arguments that I will make pertaining to the limitations on the power of the police to curtail the scope of the substantive criminal law are equally applicable to prosecutorial rulemaking.

${ }^{29}$ This broader question is, however, addressed in Part II, infra .

${ }^{30} \mathrm{Jaffe}$, Book Review, 14 VILL. L. REv. 773, 776 (1969).

${ }^{31}$ See text accompanying notes 61-62 infra.

${ }^{32}$ It is well established that we are willing to accept some selectivity in the enforcement of our penal laws. See notes $219-23$ infra \& accompanying text. For a discussion of how this selectivity ought to be controlled, see Part II infra.

${ }^{33}$ Police Discretion, supra note 14, at 112-20; Caplan, supra note 12, at 500-06;

Goldstein, supra note 12 , at $1123-31$.

${ }^{34}$ Caplan, supra note 12 , at 513. 
involved. ${ }^{35}$ The advocates of substantive rulemaking commonly acknowledge only one major point that is inconsistent with their position-the statutes that mandate the full enforcement of the criminal law by the police. ${ }^{36}$ They characterize these statutes as "naive"37 or "utter nonsense," 38 and typically continue with statements to the effect that "[i]t would seem obvious, therefore, that the issue is not which branch of government ought to assume responsibility for major policy decisions, but rather the issue is the relative functions which the legislature, the judiciary, and the administrative agency ought to play." 39 Confident that the statutes thus have been completely discredited and consequently can be ignored, the proponents of rulemaking then proceed to discuss the cogency of their proposals.

This approach ignores several fundamental problems inherent in the concept of substantive police rulemaking. In order to "conceptually ... locate the police in relation to other principal decisionmakers in the criminal law process," 40 not only must the full enforcement statutes be dealt with, ${ }^{41}$ but the policies of separation and delegation of powers also must be specifically addressed. ${ }^{42}$ Moreover, the relationship of this country's nearly unanimous rejection of the civil law doctrine of desuetude to the doctrine of separation of powers, and what that rejection suggests about the relationship of our legislatures to the police, has never been acknowledged by rulemaking's champions. ${ }^{43}$ In addition, the implications of "administrative crimes" for our separation of powers and delegation theories should be examined in the context of police rulemaking. ${ }^{44}$ Finally, the underlying policies of the separation of powers doctrine that relate to substantive rulemaking should be discussed in an attempt to determine whether those policies should be abandoned to the extent that substantive rulemaking would require. ${ }^{45}$

${ }^{35}$ But see LaFave, The Police and Nonenforcement of the Law (pt. 1), 1962 Wisc. L. Rev. 104, 105-16.

${ }^{36}$ See notes $46-62$ infra \& accompanying text.

${ }^{37}$ See text accompanying note 9 supra.

${ }^{38}$ Police Discretion, supra note 14 , at 65.

${ }^{39}$ Remington \& Rosenblum, supra note 3 , at 483.

${ }^{40}$ Goldstein, supra note 4 , at 554 .

${ }^{41}$ See Part I (A) infra.

${ }^{42}$ See Part I (B) infra.

${ }^{43}$ See Part I (C) infra.

4 See Part I (C) infra.

${ }^{45}$ See Part I (D) infra. 


\section{A. Full Enforcement Legislation}

Wayne LaFave has observed that "[a]lmost every state has some legislation relevant to police discretion," 46 and, although he is correct in his further observation that "there is a distinct lack of originality" 47 in these statutes, an examination of them makes one point abundantly clear-these statutes consistently purport to deny police the discretion not to invoke the criminal law. Twenty-three states have statutes mandating either that the law enforcement agencies arrest all who violate the criminal law or that the agencies enforce all the criminal laws; ${ }^{48}$ two more have statutes requiring peace officers to arrest all persons committing offenses in their presence, ${ }^{49}$ while two other states have directed the police to arrest all felons. ${ }^{50}$ In fact, there is general agreement $^{51}$ that the closest that any of these statutes comes to recognizing police discretion is a New Mexico provision directing law

${ }^{46}$ W. LAFAVE, supra note 6 , at 76.

${ }^{47}$ Id.

${ }^{48}$ Alaska Stat. \$ 18.65 .080 (1969); Ariz. Rev. Stat. AnN. § 11-441 (1956); Ark. Stat. ANn. §§ 12-1110 (1947), 19-1705 (Supp. 1960); Cal. Gov't. Code § 26601 (West 1968); Colo. Rev. Stat. Ann. \& 31-3-105 (1973); Conn. Gen. Stat. Rev. § 6-49 (1966); Del. Code Ann. tit. 11, § 8302 (1974); Fla. Stat. AnN. $\S 30.15$ (1974); Hawail Rev. Stat. § 6-52-67 (1968); IdAho Code \$§ 19-4804, 31-2202 (Supp. 1975); Ky. Rev. Stat. ANN. § 70.570 (1970); LA. Rev. Stat. § 15.575 (1967); ME. Rev. Stat. ANN. tit. 15, $\S 704$ (1964); Mass. ANn. Laws ch. 41, § 98 (1973); Mich. Stat. Ann. § 5-1752 (1949); Neb. Rev. Stat. § 16-323 (1974); N.M. Stat. AnN. § 15-40-2 (1953); N.D. Cent. Code § 11-15-03 (1960); OhIo Rev. Code ANn. § 737.11 (Page 1976); Utah Code ANn. \$§ 10-6-66, 17-22-2 (1953); VA. COde ANN. \$ 15.1-138 (1973); Wash. Rev. Code ANN. $\S 36.28 .010$ (Supp. 1975); W. VA. CODE ANN. § 8-14-3 (1976).

${ }^{49}$ Ill. Ann. Stat. ch. 125, $§ 82$ (Supp. 1976); Ind. Ann. Stat. $\S \S 17-3-5-2$, 18-1-11-4 (Burns 1974).

${ }^{50}$ Minn. Stat. ANN. $\$ 387.03$ (1968); Mo. ANn. Stat. § 57.100 (Vernon 1966). Although one might infer, by negative implication, that these directives to arrest "all felons" give the peace officers power not to arrest all non-felon offenders, that does not seem to be the case. Thus, the Minnesota Supreme Court, in discussing the powers and duties of sheriffs, quoted the following passage approvingly: "It is the duty of the sheriff and police officers generally to enforce those laws which the people have enacted for the protection of their lives, persons, property, health, and morals, including the laws for the observance of the Sabbath." In Re Removal of Mesenbrink As Sheriff, 211 Minn. Rpt. 114, 118, 300 N.W. 398, 400 (1941) (quoting Scougole v. Sweet, 124 Mich. 311, 323, 82 N.W. 1061, 1065 (1900)). Violation of the Sabbath Law in Minnesota is a misdemeanor. MinN. STAT. ANN. $\$ 624.03$ (1964).

Even "in jurisdictions without such . . . specific statutory definition[s], declarations of the full enforcement mandate generally appear in municipal charters, ordinances or police manuals." Goldstein, supra note 4, at 558. See authorities cited at id. n.27. The extent to which such language appears in police manuals is, of course, irrelevant to my argument. My present concern is the pervasiveness of governmental bodies enacting laws that are inconsistent with the existence of police discretion not to enforce criminal laws.

51 See, e.g., W. LAFAve, supra note 6, at 77 n.63; National Advisory Commission, supra note 23, at 23; Goldstein, supra note 4, at 557 n.26. 
enforcement officials to "investigate all violations of the criminal laws ... . which are called to [their] attention . . . and ... to diligently file a complaint or information, if the circumstances are such as to indicate to a reasonably prudent person that such action should be taken . . . ."52 Reading this statute to authorize police discretion not to enforce a criminal prohibition, however, may make it irreconcilable with another New Mexico provision directing each county sheriff to "cause all offenders to keep the peace and to appear at the next term of court and answer such charges as may be preferred against them."53 Thus, the most reasonable reading of the first statute is that it directs police officers to invoke the criminal process if an investigation of an alleged offense results in probable cause to believe that an offense was committed and that a particular person committed it. ${ }^{54}$ In short, "[t]he closest approach to express recognition of discretion in the police duty statutes" 55 most likely amounts to no such recognition at all. ${ }^{56}$

${ }^{52}$ N.M. Stat. ANN. § 39-1-1 (1972).

${ }^{53}$ N.M. STat. ANN. \$ 15-40-2 (1976).

${ }^{54}$ It does not appear that N.M. STAT. ANN. § 39-1-1 (1972) has been interpreted by the New Mexico courts, and the legislative history is not enlightening. The "reasonably prudent man" formulation in the statute, however, suggests a "probable cause" standard. As the commentary to A.L.I., Model Code of Pre-Arraignment Procedure 292 (1975) points out, there are "several formulations of the standard of belief necessary" to satisfy the probable cause requirement. See generally id. 292-96. One of these formulations is the "prudent man" standard: "If the facts and circumstances before the officer are such as to warrant a man of prudence and caution in believing that the offence has been committed, it is sufficient." Stacey v. Emery, 97 U.S. 642, 645 (1878). Cf. Terry v. Ohio, 392 U.S. 1, 27 (1968) ("[t]he issue is whether a reasonably prudent man . . would be warranted in the belief . .."). Although New Mexico usually employs a slightly different formulation, see, e.g., State v. Selgado, 76 N.M. 187, 189, 413 P.2d 469, 470 (1966) ("reasonable person"), the New Mexico Supreme Court has cited the Stacey formulation approvingly. State v. Hudson, 78 N.M. 228, 231, 430 P.2d 386, 389 (1967). Whether or not this lends support to my interpretation, I leave the reader to decide. At least there is nothing in New Mexico's law inconsistent with my view.

${ }^{55} \mathrm{~W}$. LaFAve, supra note 6 , at 77 n.63.

${ }^{56}$ There is one other category of statutes that deserves mention. A significant number of states have arrest statutes written in permissive terms. Id. 77. See, e.g., GA.

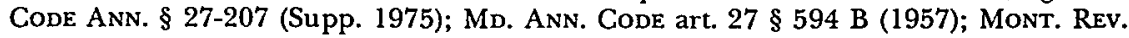
Codes AnN. § 95-608 (1968); N.Y. Crim. Pro. § 140.10 (McKinney 1970); Ore. Rev. STAT. $\$ 133.310$ (1974). These statutes generally provide that an officer may arrest under certain circumstances, such as if an offense is committed in the officer's presence or if he has reasonable grounds to believe an offense has been committed. The intent of these statutes is not to confer discretion, however, but merely to indicate when an arrest warrant is not needed. See, e.g., GA. CODE ANN. § 27-207 (1972) (commentary); Mont. Rev. Codes ANN. $\S 95-608$ (1969) (commentary). This is confirmed by the fact that a significant number of states have statutes of this type and also have statutes requiring the full enforcement of the criminal law. Compare, e.g., Alaska Stat. $\S 12.25 .030$ (1972), with § 18.65.080 (1969); ArIz. Rev. STat. ANn. § 13-1403 (1956), with § 11-441 (1956); FLA. STAT. ANN. § 901.15 (1973), with § 30.15 (1974). Moreover, 
Even if one concludes that police discretion has not received "express recognition," it may still be argued that these statutes should not be interpreted literally. As Kenneth Culp Davis concluded after reviewing the full enforcement statutes:

[A]lthough the case for literal interpretation of the full enforcement legislation is both obvious and strong, I believe the case for non-literal interpretation, though far from obvious, is unanswerable, even though it is based on a somewhat sophisticated analysis that may have little appeal to those lawyers and judges who make quick decisions without digging below the surface. ${ }^{57}$

The analysis that Davis employed to reach his conclusion is as follows:

The legislative bodies have expressed their intent in the full enforcement legislation, and they have also expressed their intent elsewhere. They have spoken with three voices. The first is the full enforcement legislation. The second is knowledge of and acquiescence in the police system of selective enforcement over a period of more than a century. Legislators know that their criminal legislation often overshoots. Their draftsman know that if they make too much criminal, the law enforcement people-police, prosecutors, and judges -will cut it back to make it sensible. Their intent often is clear that the police should not interpret criminal

there is no hint in the cases citing these "permissive" statutes that they grant discretionary power to the police.

For a complete listing of these statutes, see W. LAFAvE, supra note 6, at 77-78 n.69. Statutes revised since LaFave's book was published are as follows: ILl. REv. STAT., ch. 38, § 656, repealed, § 126-1, [1963] Ill. Laws 2836; Mont. Rev. Codes ANN. § 94-6003, repealed, ch. 196, § 2, [1967] Mont. Laws 463 (codified at Mont. Rev. Codes ANN. $\S$ 95-608 (1969); N.D. CENT. CoDE § 29-06-15, revised, ch. 258, § 1, [1967] N.D. LAws 527, ch. 91, § 4, [1969] N.D. Laws 177; ORE. Rev. STAT. § 133.310, amended, ch. 448, $\S 1,[1963]$ Ore. Laws 706, ch. 836, § 72, [1973] Ore. Laws 2725, ch. 42, § 2, [1974] Ore. Laws 127; TenN. Code ANn. $\$ 40-803$, amended, ch. 82, § 1, [1957] Tenn. Acts 271; Tex. Code Crim. Pro. art. 14.01, amended, ch 659, \& 8, [1967] Tex. Acts 1735; Utah Code ANN. $\S 77-13-3$, amended, ch. 194, \$ 11, [1971] Utah Laws 598; Wis. Stat. ANN. § 954.03, revised, ch. 255, § 63, [1969] Wis. Laws 617 (codified at Wis. STAT. ANN. § 968-07 (1971)).

${ }^{57}$ Police Discretion, supra note 14 , at 82 . In fact, Davis is the only commentator who has presented an argument for the legality of substantive rulemaking. All other proponents of rulemaking have been content to ridicule the full enforcement statutes and have not felt a need to go any further. See notes 36-40 supra \& accompanying text. Thus, if it appears that I am picking on Davis, it is only because no one else has argued the legality issue. LaFave recognizes the problem, see W. LAFAvE, supra note 6, at 60-82, but he is descriptive rather than advocatory. 
legislation literally and then enforce it fully. The third voice-the most powerful of the three-is appropriation of only enough for an estimated half to two thirds of full enforcement. ... [A]ll informed persons are in agreement that full enforcement is impossible with the present appropriation and the present system of operation. So the legislative voice in the appropriation speaks with irresistible power; the police clearly lack the resources for full enforcement. ${ }^{58}$

Davis clearly is correct that, given present levels of appropriation, full enforcement of the criminal law is impossible. ${ }^{59}$ Furthermore, resource constraints are not the only limitation on the ability to enforce "all" criminal laws. "If A and B commit a crime in a patrolman's presence and run in different directions, what does the full enforcement legislation require the patrolman to do? Run after both? Surely he cannot be required to do what is physically impossible." ${ }^{\text {" }}$ Surely not. Neither can the police as an institution "be required to do what is physically impossible"-apprehend all violators of the criminal law. Thus, Davis is justified in concluding that the full enforcement statutes cannot be read literally. He and I part ways, however, in resolving how these statutes should be read.

Davis apparently believes that since the full enforcement statutes cannot be taken as unqualified commands to enforce every criminal prohibition against all offenders, the police are free to pick and choose the statutes to be enforced, and he thinks the picking and choosing should be done by way of administrative rulemaking. ${ }^{61}$ Davis reaches this result by equating the admitted inability to enforce fully our criminal laws with the legality of a consistent practice of nonenforcement. Since such a practice is legal, he reasons, a rule authorizing or describing it must also be legal. ${ }^{62}$ Were the inability to enforce fully all the laws

58 Police Discretion, supra note 14 , at $80-81$.

${ }^{59}$ Full enforcement, as Davis recognizes, most likely would be impossible "no matter how much the resources were increased." $I d$. 81 . Some offenses will simply go undetected no matter what the resource investment.

${ }^{60}$ Id. 84-85.

${ }^{61}$ Id. 98-121.

${ }^{62}$ After asserting that a nonenforcement rule would be legal, Davis goes on to "discuss" the issue (but only because police officers, "who have no legal training," think that a nonenforcement rule would be illegal-were that not the case, Davis apparently would be willing to rest on his assertion):

The heart of the question that troubles police officers is whether the police may through nonenforcement cut back a criminal statute enacted by a legisla- 
and a consistent, legal practice of nonenforcement equivalents, the rest of his argument would be unassailable; there seems little reason not to allow a consistent, legal practice to be codified by rule. Davis' major premise, however, is invalid. The mere inability to enforce fully all laws says little about what the police are authorized to do in response to the inability. Thus, even if the police are unable to enforce "all the criminal laws," that alone does not necessarily justify the deliberate nonenforcement of any particular statute, nor does it necessarily accord the police the power to nullify penal provisions by administrative rulemaking. Similarly, "legislative acquiescence" does not further Davis' argument, even if its existence is conceded. Acquiescence in selective enforcement only proves that legislatures realize the impossibility of full enforcement. That falls far short of legitimating the power Davis wishes the police to exercise.

Moreover, Davis' solution to the problem is a legally unacceptable one. It is not enough to demonstrate that the explicit command of the full enforcement statutes cannot be heeded; the policies that shape these statutes must also be examined for insights into the proper role of the police. Davis fails to realize that substantive rulemaking flies in the face not only of the language of the full enforcement statutes, but also of the concept of gov-

tive body. The question can be better understood through a specific illustration. . . . Let us assume a hypothetical rule that the police ordinarily will not arrest a man and a woman who openly live together without marriage, in absence of special circumstances. Let us assume hypothetical facts that two graduate students, a man and a woman, both 24, live together on or near a university campus, and that their cohabitation is "open and notorious" in that their friends and acquaintances know that they live together and that they are not married. They clearly violate the words of the statute, but they are clearly within the rule because of "absence of special circumstances." Is the rule as thus applied legal?...

$\cdots$...

The police usually say that a nonenforcement rule would be illegal. But they do in fact have a consistent practice of not enforcing the statute when the facts are as assumed. So we have four questions: (1) Is nonenforcement legal? (2) May the police legally follow a consistent practice of nonenforcement? (3) Is a consistent practice an unwritten rule? (4) If an unwritten rule is legal, would a written rule to the same effect be legal?

If (1) the answer to the first question is yes, as police action says it is and as I say it is, then the answers to the other questions have to be (2) that a legal practice may be legally followed consistently, (3) that any administrator's consistent practice may properly be called an unwritten rule, and (4) that if an unwritten rule is legal a written rule to the same effect has to be legal.

Id. 91-93. Where Davis goes wrong is his assertion that the nonenforcement practice in this case is "legal." What he fails to recognize is that an inability to enforce all laws does not justify the police choosing not to enforce a particular statute. 
ernment that the statutes manifest: the principle of separation of powers.

\section{B. Separation of Powers}

The depth of this country's commitment to separation of powers as a principle of government can be gauged by examining the various state constitutions. ${ }^{63}$ All but eleven states ${ }^{64}$ have explicit constitutional provisions mandating that the executive, judicial, and legislative powers be vested in separate branches of government. ${ }^{65}$ Even the states without such explicit constitutional provisions have created their governments from the same mold. ${ }^{66}$ Moreover, these provisions are not just general directives to create three branches of government; rather, they require the creation of three branches with separate and distinct powers. Thus, they generally command that "no person or collection of persons charged with the exercise of powers properly

${ }^{63}$ The federal government is also based on separation of powers. See, e.g., U.S. Const. art. I, \& 1 ("All legislative Powers herein granted shall be vested in a Congress of the United States . . .."); U.S. ConST. art. II, \$ 1 ("The executive Power shall be vested in a President of the United States of America."); U.S. ConsT. art. III, § 1 ("The judicial Power of the United States, shall be vested in one supreme Court, and in such inferior Courts as the Congress may from time to time ordain and establish."). See also Youngstown Sheet \& Tube Co. v. Sawyer, 343 U.S. 579 (1952). I am only minimally concerned with federal separation of powers, however, because the "chief burden of administering criminal justice" rests with the state and local governments. See The PrEsident's Comm'n on LaW ENFORCEMENT and Administration of Justice, Task Force Report: Crime and Its Impact-An Assessment 55 (1967). See generally Irvine v. California, 347 U.S. 128, 134 (1954).

${ }^{64}$ The exceptions are Alaska, California, Delaware, Hawaii, Kansas, New York, North Dakota, Ohio, Pennsylvania, Washington, and Wisconsin. But see note 66 infra.

${ }^{65}$ Ala. Const. art. III, $\S \S 42,43$; ArIz. Const. art. III; Ark. Const. art. IV, $\S \S 1$, 2; Colo. Const. art. III; Conn. Const. art. II; Fla. Const. art. II, § 3; GA. Const. art. I, $\S 1$ (23); Idaho Const. art. II, § 1; IlL. Const. art. II, § 1; IND. Const. art. III, § 1; Iowa Const. art. III, § 1; Ky. Const. § 27; LA. Const. art. II, \$§ 1, 2; ME. Const. art. III, $\S$ 1, 2; MD. Const. art. 8; Mass. Const. pt. 1, art. 30; MICH. Const. art. III, § 2; Minn. Const. art. III, § 1; Miss. Const. art. I, $\$ 11,2$; Mo. Const. art. II, $\S 1$; Mont. Const. art. III, § 1; Neb. Const. art. II, § 1; Nev. Const. art. III, § 1; N.H. Const. pt. I, art. 37; N.J. Const. art. III, § 1; N.M. ConST. art. III, § 1; N.C. ConST. art. I, § 6; OkLA. Const. art. IV, § 1; Ore. Const. art. III, \& 1; R.I. Const. art. III; S.C. Const. art. I, § 8; S.D. Const. art. II; TEnN. Const. art. II, §§ 1, 2; TEX. Const. art. II, § 1; UTAH Const. art. V, § 1; VT. Const. ch. II, § 5; VA. Const. art. I, § 5, art. III; W. VA. Const. art. V, $\S 1$; WYo. Const. art. II, $\$ 1$. For a compilation of the various state constitutions, consult Legislative Drafting Research Fund of Columbia University, Constitutions of the United States: National and State (2d ed. 1974).

${ }^{66}$ See Alaska Const. arts. II, § 1, III, \& 1, IV, \& I; Cal. Const. arts. IV, \& 1, V, $\S 1$, VI, $\S 1$; Del. Const. arts. II, $\S 1$, III, $\S 1$, VI, $\S 1$; HawaII Const. arts. III, $\S 1$, IV,

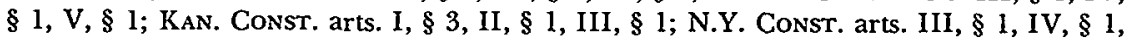
VI, § 1; N.D. ConsT. arts. II, § 25, III, § 71, IV, § 85; OHIo Const. arts. II, § 1, III, $\S 5, I V, \S 1$; PA. Const. arts. II, $\S 1 ;$ IV $, \S 1, \mathrm{~V}, \S 1$; WAsh. Const. arts. II, $\S 1$, III, $\S 1, I V, \S 1$; WIS. Const. arts. IV, \& 1, V, § 1, VII, § 2. 
belonging to one of these departments shall exercise any power properly belonging to either of the others, except as in this constitution expressly directed or permitted." ${ }^{67}$ Similar language exists in all but two of the constitutions with a separation of powers clause. ${ }^{68}$

A governmental power that must be exercised by one of these "separate and distinct"69 branches of government is, obviously enough, the legislative power. It will come as no surprise that all fifty state constitutions have vested the legislative power in the legislative branch ${ }^{70}$ although many states reserve the powers of initiative and referendum to the people. ${ }^{71}$ Consistent with the general separation of powers provisions, ${ }^{72}$ the state supreme courts have uniformly held that the legislatures are the only branch of government possessing the power to legislate. ${ }^{73} \mathrm{I}$ belabor the obvious to demonstrate not only that legislatures legislate, ${ }^{74}$ but also, and more importantly, that they are the only governmental bodies explicitly empowered to do so.

${ }^{67}$ Colo. Const. art. III.

${ }^{68} \mathrm{See}$ authorities cited in note 65 supra. R.I. Const. art. III and ConN. ConsT. art. II simply create the three departments without referring to the exercise of power. But see note 73 infra \& accompanying text.

${ }^{69}$ See, e.g., OKLA. Const. art. IV.

${ }^{70}$ Ala. Const. art. IV, § 44; Alaska Const. art. II, § 1; Ariz. Const. art. IV, § 1; Ark. Const. art. V, § 1; Cal. Const. art. IV, § 1; Colo. Const. art. V, § 1; Conn. Const. art. III, § 1; Del. Const. art. II, § 1; Fla. Const. art. III, § 1; Ga. Const. art. III, § I; Hawail Const. art. III, \& 1; Idaho Const. art. III, \& 1; Ill. Const. art. IV, § I; IND. Const, art. IV, § 1; Iowa Const. art. III, Legislative Dept. $\S 1$; Kan. Const. art. II, § 1; Ky. Const. § 29; LA. Const. art. III, § 1; ME. Const. art. IV, pt. I, § l; Mo. Const. art. III, \& 1; Mass. Const. pt. 2, ch. 1, § 1, art. I; Mich. Const. art. IV, § 1; Minn. Const. art. IV, $\S 1$; Miss. Const. art. IV, $\$ 33$; Mo. Const. art. III, $\S 1$; Monr. Const. art. V, § 1; Neb. Const. art. II, $\$ 1$; Nev. Const. art. IV, $\$ 1 ;$ N.H. Const. pt. 2, art. 2; N.J. Const. art. IV, § 1; N.M. Const. art. IV, § 1; N.Y. ConsT. art. III, § 1; N.C. Const. art. II, § 1; N.D. Const. art. II, § 25; OhIo Consr. art. II, § I; OkLA. Const. art. V, § I; OrE. Const. art. IV, § 1; PA. Const. art. II, \& 1; R.I. Const. art. IV, \& 2; S.C. Const. art. III, § 1; S.D. Const. art. III, § 1; TenN. Const. art. II, § 3; TEx. Const. art. III, § I; Utah Const. art. VI, § 1; VT. Const. ch. II, §§ 2, 6; Va. Const. art. IV, § 1; Wash. Const. art. II, § 1; W. VA. Const. art. VI, § I; Wis. Const. Art. IV, § 1; Wyo. Const. art. III, § 1 .

${ }^{71}$ See, e.g., Alaska Const. art. XII, § 11; Ark. Const. art. V, § 1 amend. 7; Ore. Const. art. II, $\$ 18$.

${ }^{72}$ See note 65 supra.

${ }^{73}$ See, e.g., Patterson v. Dempsey, 152 Conn. 431, 207 A.2d 739 (1965); Cutrona v. Mayor \& Council, 14 Del. Ch. 434, 127 A. 421 (1924); State ex rel. Young v. Duval County, 76 Fla. 180, 79 So. 692 (1918); Rich v. Williams, 81 Idaho 311, 341 P.2d 432 (1959); Koelsch v. Girard, 54 Idaho 452, 33 P.2d 816 (1934); Fergus v. Marks, 321 Ill. 510, 152 N.E. 557 (1926); State v. Butler, 105 Me. 91, 73 A. 560 (1909); Remington Arms Co. v. G.E.M. of St. Louis, Inc., 257 Minn. 562, 102 N.W.2d 528 (1960); Gardner v. City of Reidsville, 269 N.C. 581,153 S.E.2d 139 (1967).

${ }^{74}$ But see notes 110-59 infra \& accompanying text (delegation). 
Of course, merely stating that "legislatures legislate" does not dispose of the problem. As a general proposition, no one would disagree with it, which only proves the truth of Holmes' general proposition that although "the chief end of man is to frame general propositions ... no general proposition is worth a damn." 75 Hence, we must move beyond the general proposition and ask how it applies in the specific case before us. In short, the legislative power in the criminal area must be examined to see what is exclusively within its scope. Only then can the assertion that a police rule can "legally provide for nonenforcement of a criminal statute or ordinance"76 be evaluated.

Judicial interpretation of the legislative power to enact criminal statutes yields some interesting insights into the scope of this legislative power. If the courts have been adamant that only the legislatures possess the power to enact laws in general, ${ }^{77}$ they have been doubly so with respect to criminal prohibitions. ${ }^{78}$ According to the Supreme Court of Washington, "the universally accepted constitutional premise that the legislative branch of government has nearly exclusive power to define and classify crimes," qualified only by constitutional limitations, is a "fundamental concept, arising . . . out of the separations of powers."79 The Supreme Court of Mississippi has held "that the authority to define crimes and fix the punishment therefor is vested exclusively in the legislature." 80 The Supreme Court of Rhode Island concurs: "[S]ubject to constitutional limitations, the legislature alone has the power to declare what acts constitute a crime ...." 81 The three courts quoted above express "the universally accepted constitutional premise," 82 from which there seems to be no dissent. ${ }^{83}$

752 Holmes-Pollock Letters 59 (M. Howe ed. 1941).

${ }^{76}$ Police Discretion, supra note 14 , at 90.

${ }^{73}$ See note 73 supra.

${ }^{78}$ Chief Justice Marshall provided one of the earliest statements of this tenet:

The rule that penal laws are to be construed strictly, is, perhaps, not much less old than construction itself. It is founded on the tenderness of the law for the rights of individuals; and on the plain principle that the power of punishment is vested in the legislative, not in the judicial department. It is the legislature, not the court, which is to define a crime, and ordain its punishment.

United States v. Wiltberger, 4 U.S. (5 Wheat.) 574, 575-76 (1820).

${ }^{79}$ Hendrix v. City of Seattle, 76 Wash. 2d 142, 155-56, 456 P.2d 696, 705 (1969), cert. denied, 397 U.S. 948 (1970), overruled on other grounds, McInturf v. Horton, 85 Wash. 2d 704, 538 P.2d 499 (1975). See also note 85 infra.

${ }^{80}$ Howell v. State, 300 So. $2 d$ 774, 781 (Miss. 1974).

${ }^{81}$ State v. Jorjorian, 82 R.I. 334, 339, 107 A.2d 468, 470 (1954).

${ }^{82}$ Hendrix v. City of Seattle, 76 Wash. 2d 142, 155-56, 456 P.2d 696, 705 (1969).

${ }^{83}$ See, e.g., In re Lynch, 8 Cal. 3d 410, 503 P.2d 921, 105 Cal. Rptr. 217 (1972); 
One aspect of this legislative function, vested exclusively in the legislature, is the power to amend and repeal criminal statutes. As the Supreme Court of Utah has said, "The power of the legislature to repeal or amend the penalty to be imposed for crime" is "a part of the sovereign power of the state, and it is the exclusive right of the legislature to change or amend" such penal sanctions. ${ }^{84}$

Indeed, the power to amend and repeal ${ }^{85}$ is not in any significant way different from the power to enact. In enacting a law, a legislature implements a policy judgment. If the legislature subsequently determines that the policy manifested by that law is no longer to be pursued, or is to be pursued in a different way, it can repeal or amend the existing legislation. Thus, the very same process that results in a law's enactment also results in

Gilgert v. Stockton Port Dist., 7 Cal. 2d 384, 60 P.2d 847 (1936); People v. Vraniak, 5 Ill. 2 d 384, 125 N.E.2d 513, cert. denied, 349 U.S. 963 (1955); Utley v. State, 258 Ind. 443, 281 N.E.2d 888 (1972); State v. Watts, 186 N.W.2d 611 (Iowa 1971); Egan v. Sheriff, Clark County, 88 Nev. 611,503 P.2d 16 (1972); State v. Pansey, 61 Nev. 331, 128 P.2d 464, rehearing denied, 61 Nev. 348, 130 P.2d 264 (1942), overruled on other grounds, Cox v. State, 81 Nev. 48, 398 P.2d 538 (1965); People v. Blanchard, 288 N.Y. 145, 42 N.E.2d 7 (1942); People v. Ryan, 267 N.Y. 133, 195 N.E. 822 (1935); Hulsey v. State, 86 Okla. Crim. 273, 192 P.2d 301 (1948); Commonwealth v. Stottlemyer, $227 \mathrm{~Pa}$. Super. 403, 322 A.2d 725 (1974); Dendy v. Wilson, 142 Tex. 460, 179 S.W.2d 269 (1944); State v. Mundy, 7 Wash. App. 798, 502 P.2d 1226 (1972); State v. Grinstead, 206 S.E.2d 912 (W. Va. 1974). See also Stout v. State, 249 Ark. 24, 458 S.W.2d 42 (1970); Malloroy v. State, 9 Idaho 914, 435 P.2d 254 (1967); People v. Spears, 50 Ill. 2d 14, 276 N.E.2d 322 (1971); State v. Jackson, 204 N.W.2d 915 (Iowa 1973); State v. Jones, 214 Kan. 568, 521 P.2d 278 (1974); State ex rel. Sonner v. Shearin, 272 Md. 502 , 325 A.2d 573 (1974); Greenwald v. State, 221 Md. 235, 155 A.2d 894, appeal dismissed, 363 U.S. 719 (1960); State v. Kalvig, 296 Minn. 395, 209 N.W.2d 678 (1973); State v. Mathiasen, 273 Minn. 372, 141 N.W.2d 805 (1966); State v. Burrow, 514 S.W.2d 585 (Mo. 1974); Doe v. State, 114 N.H. 714, 328 A.2d 784 (1974); State v. Allen, 77 N.M. 433, 423 P.2d 867 (1967); Hazard v. Howard, 110 R.I. 107, 290 A.2d 603 (1972); Belt v. Turner, 25 Utah 2d 380, 483 P.2d 425 (1971).

${ }_{84}$ Belt v. Turner, 25 Utah 2d 380, 381, 483 P.2d 425 (1971). Accord, District of Columbia v. John R. Thompson Co., 346 U.S. 100, 114 (1953) ("The repeal of laws is as much a legislative function as their enactment."). See also Snowden v. Snowden, 1 Bland 550 (Md. 1829).

${ }^{85}$ There is an important distinction between the repeal of a statute by a legislature and the voiding of a statute on constitutional grounds by a court. Superficially, a finding of unconstitutionality may appear to require qualification of the statement that only legislatures can repeal statutes, because such a finding results in nullifying the law. The crucial distinction, however, is the basis of the "nullification." When a court finds a statute to be unconstitutional, it does so in exercise of its power to interpret the relevant constitution. When a legislature declares a statute repealed, it does so in exercise of its power to declare, and to change, public policy. Viewed in this way, a holding of unconstitutionality is not a repeal of a statute in the sense of effecting a choice among competing policies. Rather, it is a statement by a competent authority that a particular policy cannot be effected, at least in that particular manner, without violating the fundamental law of the governmental unit. An analogous distinction exists between the power to amend and the power to interpret. 
its repeal or amendment; a policy judgment is once again being implemented. ${ }^{86}$

We have, then, a model of government in which one branch is given exclusive power to declare and amend public policy ${ }^{87}$ regarding the prohibition and punishment of conduct through the criminal law. Police rulemaking affecting the scope of the criminal law is clearly inconsistent with this model, because such rulemaking would have the effect of either amending or nullifying, and thus in effect repealing, a criminal prohibition. Consider Davis' proposal that a Chicago ordinance prohibiting the consumption of alcoholic beverages in a park should not be enforced literally by the police. Davis suggests that the police should instead enact a rule providing for enforcement of the ordinance only if there is "drunkenness, noise or the disturbance of others." 88 The consequence of this rule unmistakably would be to modify the ordinance by restricting its applicability. Surely so reducing the scope of a statute amends it.

Moreover, Davis' rule would be consistent with only one possible purpose of the statute-inhibiting rowdy behavior. The legislature may have had other purposes in mind, however, such as restricting the proliferation of empty beer cans in city parks, or restricting the access of juveniles to intoxicating beverages. Perhaps the legislature simply thought it wrong to drink on public property. Davis' rule makes no accommodation for these other conceivable purposes of the statute, and if the legislature intended to accomplish any of them, his rule directly amends the statute.

If there is no significant difference between the amendment of legislation and police rulemaking having the same effect, Davis' proposal cannot be reconciled with a theory of gov-

${ }^{86}$ With respect to the criminal law, there is one difference between enacting and repealing that deserves mention. When a criminal law is enacted, the result generally is a decrease in freedom, whereas repeal usually has the opposite effect. This distinction does not further Davis' argument, however, since it suggests nothing at all about the inherent power of the police vis-à-vis the legislature under the separation of powers doctrine; nor does it suggest anything about which body of government should, as a policy matter, make the determination to criminalize specified conduct. See text accompanying note 124 infra.

${ }^{87}$ In one sense, the power to declare public policy is shared with the executive through the veto power. That is not inconsistent with my argument, however, since the veto power can only be invoked upon the passage of a bill by the legislature. In fact, to the extent that an explicit grant of power tends to deny the existence of implicit power, the veto power confirms my position.

${ }^{88}$ Police Discretion, supra note 14 , at 159-60. 
ernment based on the separation of powers doctrine. If only the legislature can articulate public policy of this sort, then obviously the police are forbidden to do so. Of course, it is possible that the separation of powers "model" discussed above does not reflect reality ${ }^{89}$ Thus, before one can conclude that the legislatures are the exclusive articulators of criminal law policy in our system, and consequently that substantive rulemaking is inconsistent with our theory of government, the application of the separation of powers model in two areas-desuetude and the delegation of powers-must be examined. Such an investigation will confirm the extent to which we have tried to make reality conform to theory, and how committed we are to the legislature being the exclusive policy formulator in the field of substantive criminal law.

\section{Separation of Powers Applied: Desuetude and Delegation.}

"Desuetude" is the ancient doctrine ${ }^{90}$ that long and continuous failure to enforce a statute, coupled wih open and widespread violation of it by the populace, is tantamount to repeal of the statute:

Long continued custom is not improperly regarded as equivalent to a statute, and what is . . established by usage is law .... Wherefore very rightly this also is held, that statutes may be abrogated not only by a vote of the legislator, but also by desuetude with the tacit consent of all. ${ }^{91}$

Although there is some dispute over how well desuetude has fared elsewhere, ${ }^{92}$ courts in the United States have consistently rejected it. ${ }^{93}$ As Professor Arthur Bonfield, perhaps our most

${ }^{89}$ See, e.g., Allen, Retribution in a Modern Penal Law: The Principle of Aggravated Harm, 25 BUFF. L. REv. 1, 18 n.65 (1975).

${ }^{90}$ The roots of desuetude go back at least as far as the Roman jurist Julian. Bonfield, The Abrogation of Penal Statutes by Nonenforcement, 49 Iowa L. Rev. 389, 395 (1964). For a discussion of the doctrine's lineage, see id. 395-409. See also T. Plucknett, A Concise History of the Common LAw 337-41 (5th ed. 1956).

91 Bonfield, supra note 90 , at 395 (quoting Digest 3.32.1).

${ }^{92}$ Compare T. Plucknet, supra note 90, at 337 ("On the continent there was some speculation during the middle ages as to whether a law could become inoperative through long-continued desuetude."), with Bonfield, supra note 90, at 400 ("The previous survey demonstrates that the civilian tradition has sometimes recognized that a protracted failure to enforce a statute in the face of its widespread disregard may abrogate it.").

${ }^{93}$ Cates, Can We Ignore Laws?-Discretion Not to Prosecute, 14 AlA. L. Rev. 1 (1961); 
eminent authority on desuetude, ${ }^{94}$ summed up the American experience after an exhaustive review of the authorities: "American courts have come to mouth the view that the vitality of an enacted law can never be impaired by a failure to enforce it. .. . Desuetude is summarily and completely written off as alien to our law." 95 In the decade since Bonfield wrote, desuetude has fared no better: it was rejected in every case in which it was raised. ${ }^{96}$

The basis of this consistent rejection of desuetude by the courts is a respect for the doctrine of separation of powers. The impropriety of a court usurping the legislative prerogative by declaring an act repealed by desuetude was recognized a century and a half ago:

No judge or court, either of the first or last resort, can have any right to legislate; and there can be no difference between the power to declare an act of Assembly obsolete and the power to enact a new law. The power to repeal and to enact are of the same nature. I shall therefore always consider an express provision of a constitutional act of Assembly as an authority superior to any usage $\ldots$. whatever. $^{97}$

What was recognized so long ago recently has been reaffirmed. "[T] he general rule is that a statute is not repealed by nonuse. The argument . . . may be a cogent one when addressed to the legislature, yet courts of justice cannot and do not recognize such a policy as a basis for their decision." ${ }^{\text {"9 }}$

Moreover, the rejection of desuetude does not stand solely for the proposition that courts are unwilling to assume that they have "the power to cast votes in the legislature." ${ }^{\text {R9 }}$ Rather, these

Rodgers \& Rodgers, Desuetude as a Defense, 52 Iowa L. Rev. 1 (1966). But see Bonfield, supra note 90 , at $423-40$.

${ }^{94}$ See Bonfield, supra note 90; Bonfield, The Guarantee Clause of Article IV, Section 4: A Study in Constitutional Desuetude, 46 MinN. L. Rev. 513 (1962).

95 Bonfield, supra note 90 , at 429 . It should be noted that Bonfield is greatly distressed by this result. Id. For a discussion of Bonfield's position, see note 101 infra.

${ }^{96}$ See, e.g., United States v. Elliott, 266 F. Supp. 318 (S.D.N.Y. 1967); Department of Pub. Safety v. Freeman Ready-Mix Co., 292 Ala. 380, 295 So. 2d 242, appeal dismissed sub nom. Southern Haulers v. Department of Pub. Safety, 419 U.S. 891 (1974); State v. Egan, 287 So. 2d 1 (Fla. 1973); Gibson Products Co. v. Lowe, 440 S.W.2d 793 (Ky. 1969); Doe v. O'Brien, 107 N.H. 79, 217 A.2d 189 (1966). Cf. Helland v. King County Civil Serv. Comm'n, 84 Wash. 2d 858, 529 P.2d 1058 (1975). For a collection of other cases rejecting desuetude, see Rodgers \& Rodgers, supra note 93, at 2 n.4.

${ }^{97}$ Snowden v. Snowden, 1 Bland 550, 556 (Md. 1829). But see note 101 infra.

${ }^{98}$ State v. Egan, 287 So. 2d 1, 7 (Fla. 1973).

9s Rodgers \& Rodgers, supra note 93, at 19. 
decisions represent a particular view of the appropriate role of the executive branch. "The doctrine of separation of powers ... stands in the way of holding that a legislative enactment which complies with constitutional requirements can be rendered ineffective by non-use or obsolescence or repealed by failure of those entrusted with its administration to enforce it." ${ }^{100}$ In short, the rejection of desuetude is only superficially a limitation on the judiciary. ${ }^{101}$ Its essence is a limitation on the executive.

${ }^{100} \mathrm{~J}$. Sutherland, IA Statutes and Statutory Construction $\$ 23.25$, at 267 (Sands ed., 4th ed. 1972).

${ }_{101}$ Professor Bonfield believes that the courts have ignored important constitutional problems in rejecting desuetude as a defense to a criminal charge. See Bonfield, supra note 90, at 423-40. His argument has two parts. First, desuetudenal statutes that can be resurrected by criminal law administrators confer too much discretion to choose whom to prosecute. "A continuing ability to revitalize desuetudenal enactments tempts and facilitates ad hoc invidiously discriminatory prosecutions of the kind feared in the commonly-voided overly-discretionary statutes." Id. 413-14. Second, when a law has not been enforced for a considerable period of time, a citizen no longer has notice of it.

The due-process clauses of the fifth and fourteenth amendments require both state and federal governments to frame their criminal statutes so that those to whom they are addressed may know exactly what conduct is proscribed. In applying this fair-notice test imposed by due process, the court must first look through the eyes of the individual-giving due account to community usage, common experience, and the provision's actual significance within the body politic.

A penal enactment which is linguistically clear, but has been notoriously ignored by both its administrators and the community for an unduly extended period, imparts no more fair notice of its proscriptions than a statute which is phrased in vague terms.

Id. 416 (footnotes omitted).

Bonfield ascribes the failure of the courts to see these issues to the fact that "most of the authorities responsible for the American repudiation of desuetude are state court cases ... derive[d] from an era antedating the formulation or articulation of the relevant constitutional doctrines involved." $I d$. 429. The state courts, however, have continued to reject desuetude as a defense. Thus, the argument cannot now be made that desuetude has been rejected simply because the relevant constitutional principles have not been adequately developed. Even after their development, not one state has embraced desuetude as a principle of law.

Bonfield also argues that the Supreme Court's opinion in Poe v. Ullman, 367 U.S. 497 (1961), supports his position. See Bonfield, supra note 90, at 435-39. Events subsequent to his article, however, demonstrate that Bonfield's reliance on Poe was misplaced. In $P o e$, a declaratory judgment action, the Court refused to decide the constitutionality of two Connecticut criminal statutes that penalized the use of contraceptive devices, but apparently had been long unenforced. 367 U.S. at 502. In light of Connecticut's failure to enforce the laws, Justice Frankfurter, writing for the Court, dismissed the case as not raising a justiciable issue: "The fact that Connecticut has not chosen to press the enforcement of this statute deprives these controversies of the immediacy which is an indispensable condition of constitutional adjudication." Id. at 508 . In reaching this conclusion the Court touched on the problem of desuetude:

The unreality of these law suits is illumined by another circumstance. We were advised by counsel for appellants that contraceptives are commonly and notoriously sold in Connecticut drug stores. Yet no prosecutions are recorded; and certainly such ubiquitous, open, public sales would more quickly invite the 
The rejection of desuetude in deference to the principle of separation of powers represents not only a recognition of the executive branch's inability to repeal a statute. More importantly for our purposes, it also represents a recognition of the executive's duty to enforce the laws that are enacted. The rejection of desuetude thus amounts to a recognition that when the executive moves to enforce an "ancient sleeping statute," 102 it is merely

attention of enforcement officials than the conduct in which the present appellants wish to engage-the giving of private medical advice by a doctor to his individual patients, and their private use of the devices prescribed. The undeviating policy of nullification by Connecticut of its anti-contraceptive laws throughout all the long years that they have been on the statute books bespeaks more than prosecutorial paralysis. What was said in another context is relevant here. "Deeply embedded traditional ways of carrying out state policy ..."-or not carrying it out-"are often tougher and truer law than the dead words of the written text."

Id. at 502 (footnotes omitted).

Bonfield read this case as embracing desuetude, and he was not alone in his belief. Alexander Bickel went so far as to say that the "consequence of the opinion . . . must be that a prosecution of persons [under the statute] ... would fail on the ground of desuetude." Bickel, The Supreme Court 1960 Term, Forward: The Passive Virtues, 75 Harv. L. REv. 40, 64 (1961). Bickel's prediction proved to be inaccurate, however. The Court subsequently heard a case in which the Connecticut statutes had been enforced, and the Court found that the statutes unconstitutionally interfered with the right to privacy emanating from the marriage relationship. Griswold v. Connecticut, 381 U.S. 479 (1965). Moreover, the opinion for the Court did not even mention desuetude, which is not surprising since its author, Justice Douglas, said in Poe that desuetude was "contrary to every principle of American or English common law." 367 U.S. at 511 (Douglas, J., dissenting). It is possible, however, that I am reading too much into Griswold, because the petitioner apparently did not raise the desuetude issue. Rodgers \& Rodgers, supra note 93, at 8 \& n.48. For a more complete discussion of Griswold, see Kauper, Penumbras, Perepheries, Emanations, Things Fundamental and Things Forgotten: The Griswold Case, 64 Mich. L. REv. 235 (1965). For criticisms of Bickel's (and Bonfield's) view, see Gunther, The Subtle Vices of the "Passive Virtues"-A Comment on Principle and Expediency in Judicial Review, 64 Colum. L. REv. 1, 16, 20 (1964); Comment, Threat of Enforcement -Prerequisite of a Justiciable Controversy, 62 Colum. L. Rev. 106 (1962).

I must admit that some of Bonfield's fears do seem to be found lurking in the background of many cases, even though desuetude has apparently been so thoroughly rejected. See, e.g., People v. Acme Markets, 37 N.Y.2d 326, 334 N.E.2d 555, 372 N.Y.S.2d 590 (1975). Moreover, a court's determination that a statute was unconstitutional based on due process notice considerations would be inconsistent with my argument to the extent that the lack of notice resulted from the executive's failure to enforce a statute. Such a holding would have the effect of granting the executive power to repeal the statute. Perhaps that is why the courts do not, or at least have not, decided cases on that basis. The potential for abuse emanating from long dormant laws often seems to trouble courts, but they usually find a way to dispose of the case without resort to desuetude. For example in Acme, supra, the court held that Sunday sales laws could not be invoked merely to further the economic interests of the complainants. The lack of enforcement allowed the court to conclude as a factual matter that the statute was being used to further an improper motive; the court did not hold that the law could not now be enforced under any circumstances. Indeed, the court may have been calling for evenhanded enforcement of the statute.

${ }^{102}$ Wright v. Crane, 13 Serg. \& Rawl. 446, 452 (Pa. 1826). 
doing "what it should have done in the first place"; ${ }^{103}$ the executive is no more empowered to nullify indirectly the legislative will than it is to do so directly. ${ }^{104}$

Consider what the rejection of desuetude as a principle of our law suggests about the power of the police to provide by rule for the nonenforcement of a criminal statute. As I have already shown, ${ }^{105}$ such a rule would, in effect, amend or repeal the relevant statute. ${ }^{106}$ If a law cannot be "rendered ineffective . . . by

\section{${ }^{103}$ Rodgers \& Rodgers, supra note 93, at 18.}

${ }^{104}$ While it is true that the executive does on occasion "nullify the legislative will," that does not detract from my argument that such action is lawless. Whether there is an effective way to deal with such action, however, is quite another issue. A court could "order" the executive to enforce a law through a mandamus proceeding, but if the executive does not comply, there is little that can be done. Theoretically the court could jail the officials who failed to enforce the law for contempt. The judicial branch is not likely, however, to take such action, at least not on any significant scale, because its power depends on the good will of the executive. There is no better example of this problem than the dispute that arose over the Supreme Court's decision in the Cherokee Cases of 1831. Cherokee Nation v. Georgia, 30 U.S. (5 Pet.) 1 (1831). President Jackson, not in sympathy with the decision, reputedly said, "Well, John Marshall has made his decision, now let him enforce it." 1 C. WARren, The Supreme Court IN United States History 759 (1926). John Marshall, of course, could not enforce his decision, and as a result there arose "the most serious crisis in the history of the Court"-a crisis that was resolved, in large part, by President Jackson's coming to the Court's rescue. Id. 729-79. This crisis illustrates the fact that the power of the judiciary rests largely on the willingness of the other branches of government, and in particular the executive, to respect our constitutional scheme of separation of powers. In short, the judiciary is relegated to admonishing the executive branch to do its duty, which is precisely the point of the desuetude cases. See generally A. Bickel, The Least Dangerous Branch (1962). But see note 224 infra.

${ }^{105}$ See notes 84-89 supra \& accompanying text.

${ }^{106}$ Davis, however, would argue that the police would be only "interpreting" the affected statute. See, e.g., Police Discretion, supra note 14, at 159-60. This argument is based on the distinction between "legislative rules" and "interpretative rules." See Administrative Law Treatise, supra note $16, \S 5.03$. Legislative rules "cannot be validly issued in absence of a legislative grant of power to make rules having force of law." Police Discretion, supra, at 110. Interpretative rules, however, can be promulgated without a legislative grant of rulemaking power. Id.; see Skidmore v. Swift \& Co., 323 U.S. 134 (1944). Although a court may invalidate a legislative rule if it is unreasonable or is not within the granted power, a court may not substitute its own judgment for the substance of the rule. Interpretative rules, on the other hand, are not controlling upon reviewing courts, although courts often accord them great weight in interpreting the relevant statute. AdMinistrative LAw TREATISE, supra note $16, \$ 5.03$.

By labeling rules promulgated by the police "interpretative," Police Discretron, supra, at 108-12, and by noting that "interpretative rules . . do not necessarily have the force of law," $i d$. 110, Davis attempts to demonstrate that police rulemaking does not raise any constitutional problems. But the fact that police rules would not "necessarily have the force of law," because the courts must make the final determination of the law covered by the rules, does not support Davis' position. Unlike the administrative law cases such as Skidmore v. Swift E Co., supra, relied on by Davis, see Police Discretion, supra, at 109-11, police rules restricting the scope of the substantive criminal law generally will not be challenged in the courts because no individual will be affected adversely by such rules. Thus, in practice judicial review of police rules would be infrequent, and 
failure of those entrusted with its administration to enforce it"107 over a long and continuous period of time, and in the face of known widespread violations, what power is there for "those entrusted with its administration" to render that law ineffective by rule simply because in their judgment it is not a wise enactment? ${ }^{108}$ The analogy is a powerful one, and compels the conclusion that the police may not "legally provide for nonenforcement of a criminal statute or ordinance." 109

This conclusion is supported further by the role that the principle of delegation of powers plays in the criminal law. As a general matter the exclusivity of the legislature's policy formulation role is admittedly compromised by the delegation of powers doctrine. In response to an increasingly complex civilization that generated demands for the regulation of highly technical relationships and that required "a course of continuous decision,"110 our legislatures, particularly Congress, began to delegate power to administrative agencies. ${ }^{111}$ These grants of power were originally sustained, despite claims that the separation of powers doctrine forbade the legislature from delegating its lawmaking function, ${ }^{112}$ "by drawing a theoretical distinction between legisla-

police rules would have de facto the force of law.

A more fundamental objection to Davis' legislative-interpretative argument is its implication that labeling may affect the substance of what is labeled. Shakespeare long ago disposed of that argument. Romeo and Juliet, Act II, sc. ii, 1l. 43-44 ("That which we call a rose by any other name would smell as sweet."). Whatever police rules are called, if their effect is to restrict the scope of the substantive criminal law the desuetude cases make clear that such rulemaking would be a usurpation of legislative power. See text accompanying notes 90-106 supra \& 106-09 infra. Moreover, although Davis suggests that the source of power to write a rule determines whether it is interpretative or legislative, this says nothing about the extent of a police department's power to promulgate rules, and the very issue is whether the police have the power to engage in "substantive rulemaking" that would reduce the scope of the criminal law. For the definition of "substantive rulemaking" for purposes of this Article, see note 26 supra.

I do not quarrel with Davis' argument that the police may interpret laws. But see note 222 infra. That argument, however, fails to confront the problem of determining when interpretation so affects the scope of the criminal law as to amend it and thus become "substantive rulemaking." Whether police rulemaking is labeled legislative or interpretative is irrelevant to that inquiry.

${ }^{107} \mathrm{~J}$. SUT HERLAND, supra note $100, \S 23.25$, at 267.

${ }^{108}$ See note 179 infra.

${ }^{109}$ Police Discretron, supra note 14 , at 90 . Of course, Davis was making the opposite point.

110 L. Jaffe, Judicial Control of Administrative Action 36 (1965). See 1 J. Sutherland, Statutes and Statutory Construction $\$ \$ 3.31-4.27$ (Sands ed., 4th ed. 1972).

${ }^{111}$ L. JAFFE, supra note 110 , at 28-41. A few state constitutions specifically provide for the creation of regulatory agencies. See, e.g., Alaska Const. art. III, \& 22.

112 There is disagreement concerning the relationship of the delegation and separation of powers doctrines. Sutherland says that "[l]imitations on the delegation of gov- 
tive power and a subsidiary power to fill up the details or to find facts to carry the legislatively declared policies into effect." 113

The "theoretical distinction" proved neither workable nor accurate. Societal demands for the delegation of broad powers to administrators quickly outpaced the original justification of the practice, and the inevitability of delegation of power soon became evident. "Indeed," says Louis Jaffe, "every statute is a delegation of lawmaking power to the agency appointed to enforce it."114 Consequently, broader and broader delegations of power to administrative agencies have been sustained, leading one commentator to conclude that there are now few significant limitations on the delegation of legislative powers. ${ }^{115}$ Regardless of how true that might be in the federal system, ${ }^{116}$ our concern is with delegation in the states. Moreover, our concern is with the delegation of power in a particular area-the substantive criminal law. When the sights are narrowed accordingly, what emerges is a conception of delegation much different from that discussed above.

Delegation of powers has not been accorded the broad general approval in the states that it has received in the federal system. The states "have pursued a wavering course. The archaic, narrow formulation [of separation and delegation of powers] is sometimes taken seriously and is as frequently disregarded."117

ernmental powers are in some sense a corollary of the separation doctrine." J. SUTHERLAND, supra note $110, \S 4.02$, at 73. Bickel, on the other hand, thinks that "[t]o say that the doctrine of delegation is concerned with the separation of powers is merely to invoke a symbol." A. BICKEL, supra note 104, at 160. Louis Jaffe perhaps has expressed the relationship most accurately of all: "The three great classes, with the aid of specific constitutional allocations of authority, establish three polar functions; in the polar areas there is an intelligible doctrine which the courts have seen fit to enforce. But beyond those areas logic tolerates and convenience dictates concurrent jurisdiction and combination of functions." L. JAFFE, supra note 110 , at 28.

${ }^{113}$ Administrative Law Treatise, supra note 16, \& 2.02, at 77.

${ }^{114} \mathrm{~L}$. JAFFE, supra note 110 , at 35 . The example he uses to illustrate his point is jurisdiction: "[T] he power to declare the law applicable to a case, is the power to apply a general formula to a specific situation. This power when exercised by the judiciary is ordinarily called interpretation or discovery of the legislative intention." Id.

${ }^{115}$ Discretionary Justice, supra note 5, at 40-50. Davis feels that the nondelegation doctrine should be replaced by a requirement that administrators clarify the scope of their authority in the face of an open-ended grant of discretionary power. Id. For a criticism of this view, see Wright, Book Review, 81 Yale L.J. 575, 582-87 (1972). Davis' position is largely predicated upon the fact that the United States Supreme Court has rarely (only twice) struck down a statute on the grounds of impermissible delegation. But, as Jaffe points out, Davis' analysis overlooks the "cautionary effect on legislative practice" that the two cases have had. Jaffe, supra note 30 , at 773 .

${ }^{116}$ See Administrative Law Treatise, supra note 16, at $\$ \$ 2.01-2.04$.

${ }^{117}$ L. JAFFe, supra note 110 , at 73. As Jaffe points out, the competing policies include a dislike for administrative activity on the one hand, and the wide variety of 
With respect to the criminal law, however, "state courts have taken more literally [than the federal courts] the doctrine of the exclusive function of the legislature to create a criminal offense." 118 In fact, the state courts have generally either denied entirely the power to delegate with respect to the scope of the criminal law or have permitted delegation only in certain limited circumstances.

The recent Mississippi Supreme Court decision in Howell $v$. State $^{119}$ is illustrative of the decisions prohibiting state legislatures from delegating to administrative agencies any power to affect the scope of the substantive criminal law. Under Mississippi's Uniform Controlled Substances Law, controlled substances are classified into five schedules. ${ }^{120}$ The legislature promulgated the original schedules, but the power to add, delete, or reschedule any substance, subject to specific guidelines, was delegated to the State Board of Health. ${ }^{121}$ Under this authority the Board shifted amphetamines from Schedule III to Schedule II. An effect of this change was to raise the maximum sentence for unlawful possession of amphetamines from one year to two. Subsequently, the defendant was convicted of unlawful possession, and was sentenced to two years in the state penitentiary. ${ }^{122}$

The defendant argued on appeal that the statute authorizing the Board to reschedule substances constituted an unconstitutional delegation of power insofar as penalties for a violation

problems facing the states on the other. Id. See also 1 F. Cooper, State Administrative Law I6-29 (1965); Administrative Law Treatise, supra note 16, § 2.07, at 101-02.

${ }^{118}$ Schwenk, The Administrative Crime, Its Creation and Punishment by Administrative Agencies, 42 Mich. L. Rev, 51, 59 (1943).

119300 So. 2d 774 (Miss. 1974).

120 Miss. Code ANN. \$§ 41-29-113 to 121 (1972).

${ }^{121}$ For example, MIss. CoDE ANn. $\S 41-29-111$ provides the following guidelines for the Board's determination to control a substance:

In making a determination regarding a substance, the board shall consider the following:

(a) (1) The actual or relative potential for abuse;

(2) The scientific evidence of its pharmacological effect, if known;

(3) The state of current scientific knowledge regarding the substance;

(4) The history and current pattern of abuse;

(5) The scope, duration and significance of abuse;

(6) The risk to the public health;

(7) The potential of the substance to produce psychic or physiological dependence liability; and

(8) Whether the substance is an immediate precursor of a substance already controlled under this article.

Additional standards are provided in MISs. CODE ANN. $\$$ 41-29-113 to 121.

122300 So. $2 \mathrm{~d}$ at 775,779 . 
of the Act were determined by the schedule a substance was assigned to by the agency. The court agreed:

It is readily apparent that when the State Board of Health shifted amphetamines from Schedule III to Schedule II, the maximum penalty for possession thereof increased. The practical effect of moving a substance from one schedule and placing it in another is to increase or diminish the criminal penalty for violation of the act. It is likewise true that, if substances are added to or deleted from any of the schedules such action makes acts pertaining to the substances so added a crime, and as to substances deleted, abolishes a crime. The result is that the State Board of Health is given the authority to define a crime, and ordain its punishment.

We hold that the authority to define crimes and fix the punishment therefor is vested exclusively in the legislature, and it may not delegate that power either expressly or by implication, but must exercise it under Article 4, Section 33 of the Constitution. We further hold that the attempted delegation of power to the State Board of Health is contrary to Article 1 , Sections 1 and 2 of the Constitution providing for separation of the powers of the government of the state into three departments. The State Board of Health is an administrative agency and as such is a part of the executive department of the state. When it rescheduled amphetamines from Schedule III to Schedule II, it increased the punishment of Howell in excess of that fixed by the legislature and thereby exercised legislative power. This infringes on the separation of the powers of government and is prohibited. ${ }^{123}$

Howell thus stands for the proposition that in Mississippi the power to define criminal offenses rests exclusively with the legislature, and may not be delegated. Although the Board of Health's action in Howell caused an increase in the defendant's sentence, ${ }^{124}$ the language quoted above makes clear that the authority to abolish a crime may no more be delegated than the authority to increase a criminal penalty. Moreover, the legislature apparently may not delegate even a fact finding role to an

${ }^{123} 300$ So. $2 \mathrm{~d}$ at $779-81$ (emphasis supplied).

${ }^{124}$ See text accompanying note 86 supra. 
administrative agency if the factual determination would expand or restrict the scope of the criminal law or modify the relevant sanctions. This is true even if, as in Howell, the factual determination is a complex matter calling for highly sophisticated techniques and skills. If the State Board of Health cannot promulgate such rules pursuant to explicit statutory authorization in an area where the Board is presumably highly skilled, surely the police have no general power to do so. Thus in Mississippi, the police are apparently powerless to restict the scope of the substantive criminal law by rulemaking.

Howell, however, does not state the majority position in the United States. Although there is significant support for Howell's "old-fashioned"125 view, ${ }^{126}$ the majority of state courts have allowed the legislatures to delegate some power to administrative agencies to promulgate rules having an impact on the substantive criminal law. ${ }^{127}$ An examination of the case law authorizing the delegation of rulemaking power to administrative agencies and upholding statutes that criminalize violations of the rules and regulations promulgated pursuant to such authority ${ }^{128}$ will demonstrate, however, that the scope of this authorization is so narrowly circumscribed that delegation to the police of the substantive rulemaking powers advocated by Davis is precluded.

State courts have often allowed agencies, pursuant to delegated authority, to promulgate rules with criminal sanctions for violations, as long as it is the statute itself that declares the violation to be criminal. ${ }^{129}$ These grants of delegated authority, how-

${ }^{125} \mathrm{Cf}$. Schwenk, supra note 118 , at 61 .

126 Dent v. United States, 8 Ariz. 138, 71 P. 920 (1903), rev'd on other grounds, 76 P. 455 (1904); Casey v. People, 139 Colo. 89, 336 P.2d 308 (1959); People v. Yonker, 351 Ill. 139, 184 N.E. 228 (1932); State v. Brunt, 246 La. 99, 163 So. 2d 551 (1964); State v. Maitrejean, 193 La. 824, 192 So. 361 (1939); State v. Workmen, 186 Neb. 467, 183 N.W.2d 911 (1971); Lincoln Dairy Co. v. Finigan, 170 Neb. 777, 104 N.W.2d 227 (1960); Williams v. State, 146 Tex. Crim. 130, 176 S.W.2d 177 (1943). Cf. Mo. Const. art. I, $\S 31$ ("[N]o law shall delegate to any ... administrative agency authority to make any rule fixing a fine or imprisonment as punishment for its violation.").

${ }_{127}$ See Schwenk, supra note 118. See also L. JAFFE, supra note 110, at 109-15.

${ }^{128}$ The power of agencies to both prescribe and impose civil sanctions has long been upheld. See Schwenk, supra note 118, at 75-77; Administrative Law Treatise, supra note 16 , at $\S 2.13$. Some early commentators, however, rejected the distinction between civil and criminal sanctions. Brown, Administrative Commissions and the Judicial Power, 19 Mins. L. REv. 261, 293-95 (1935); Cheadle, The Delegation of Legislature Functions, 27 Yale L.J. 892, 918 (1918). For a discussion of this distinction, see Schwenk, supra; Administrative LAw TREATISE, supra, at \$ 2.13.

${ }^{129}$ The courts have embraced the theory that when a statute provides the penalties for violation of rules promulgated by an agency, it is the legislature, not the agency, that penalizes the conduct. See United States v. Grimaud, 220 U.S. 506 (1910). The 
ever, have been upheld only in limited areas such as economic regulation, and health and welfare regulations. Even then the courts usually require a precise legislative standard.

For example, when an agency is created to regulate an industry, it is often empowered, of necessity, to formulate policies and issue rules and regulations. The courts have sustained these grants of power, even when penal sanctions are involved. The most prevalent example is the alcoholic beverage industry, ${ }^{130}$ which traditionally has been regulated heavily. ${ }^{131}$ Agencies without this historical tradition, however, have also beet empowered to formulate policies for the governance of airports ${ }^{\mathbf{1 3 2}}$ and the regulation of various aspects of the trucking ${ }^{133}$ and fishing ${ }^{134}$ industries. Other decisions have upheld the delegation of power to write rules and regulations to protect the public welfare. For example, sanitation codes have been upheld when written by

distinction between statutes that make the violation of rules an offense and those that permit the agency to decide which rules shall be enforced by penal sanctions has little to commend it, as a comparison of two New York cases demonstrates. In People v. Ryan, 267 N.Y. 133, 195 N.E. 822 (1935), the court of appeals struck down a law that authorized the Alcoholic Beverage Control Board to promulgate rules and that gave the Board discretion to make violation of the rules a misdemeanor. Seven years later, in People v. Blanchard, 288 N.Y. 145, 42 N.E.2d 7 (1942), the court of appeals upheld a statute that penalized any violation of the Sanitation Code as formulated by the Board of Health pursuant to statutory authority. The court distinguished Ryan by stating that in Blanchard the legislature penalized the act involved, while in Ryan the agency was empowered to create crimes. This distinction makes little sense:

The reasoning ... would be correct if the penalty were the only essential of a criminal offense. However, a crime consists of two components: the elements . . . as well as the penalty. Consequently, if the legislative act does not contain both, the criminal offense has not come into existence.

Schwenk, supra note 118, at 57. See also Gellhorn, Administrative Prescription and Imposition of Penalties, 1970 WASH. U.L.Q. 265.

Decisions like Blanchard may also be counterproductive to the extent that one of their purposes is to restrict the proliferation of criminal offenses. Because of the court's emphasis on which body makes the criminalization decision, in Blanchard every rule promulgated pursuant to legislative authorization will be backed by a penal sanction, whereas in Ryan only selected rules of the Alcoholic Beverages Control Board would have had penal sanctions. See, e.g., Gellhorn, supra, at $268 \mathrm{n} .9$.

${ }^{130}$ See, e.g., Boehl v. Sabre Jet Room, Inc. 349 P.2d 585 (Alaska 1960); Wilke \& Holzheiser, Inc. v. Department of Alcoholic Beverage Control, 65 Cal. 2d 349, 420 P.2d 735, 55 Cal. Rptr. 23 (1966); Glustro v. State, 206 Ga. 734, 58 S.E.2d 534 (1950); Kentucky Alcoholic Beverage Control Bd. v. Klein, 301 Ky. 757, 192 S.W.2d 735 (1946); State v. Parham, 412 P.2d 142 (Okla. 1966).

131 "[T] he retail liquor business has always been placed in a class by itself . . .." Kentucky Alcoholic Beverage Control Bd. v. Klein, 301 Ky. 757, 760, 192 S.W.2d 735, 737 (1946) (quoting Schierman v. Town of Highland Park, 130 Ky. 537, 546, 113 S.W. 507,509 (1908).

${ }^{132}$ Commonwealth v. Diaz, 326 Mass. 525, 95 N.E.2d 666 (1950).

${ }^{133}$ Frazier v. State, 267 P.2d 155 (Okla. Crim. Ct. App. 1953).

134 Bay Towing \& Dredge Co. v. State, 40 Ala. App. 276, 111 So. 2 d 919 (1959). 


\section{agencies, ${ }^{135}$ as have fire regulations ${ }^{136}$ and regulations pertain-} ing to public facilities. ${ }^{137}$

In all these decisions upholding delegations of rulemaking authority backed by penal sanctions to an agency, the subject matter required particular skills or attributes that could not reasonably be demanded of a legislature. ${ }^{138}$ The required skill is

135 People v. Blanchard, 288 N.Y. 145, 42 N.E.2d 7 (1942).

${ }^{136}$ Moore v. Municipal Court, $170 \mathrm{Cal} .2 \mathrm{~d}$ 548, 339 P.2d 196 (1959).

${ }^{137}$ State v. Willburn, 49 Hawaii 651,426 P.2d 626 (1967). See also State v. Cunningham, 85 Ohio L. Abs. 469, 168 N.E.2d 552 (1960) (traffic regulations); Lane v. Holderman, 40 N.J. Super. 324, 123 A.2d 56 (1956), modified, 23 N.J. 304, 129 A.2d 8 (1957) (wage regulations).

${ }_{138}$ There appears to be a more fundamental distinction lurking below the surface of cases upholding delegations of rulemaking authority backed by penal sanctions. The "penal sanctions" involved in these cases have "nothing to do with the ordinary concept of crime." Schwenk, supra note 118 , at 86. Regardless of the form they take, the method of application, or the label applied to them, these sanctioning devices are fundamentally different from our basic conception of a penal sanction. They are not imposed as an "emphatic denunciation by the community of a crime," Royal Commission on Capital Punishment, Cmd. No. 8932, 53 (1953) (Testimony of Lord Justice Denning), nor are they employed as "device[s] for the expression of attitudes of resentment and indignation, and of judgments of disapproval and reprobation." J. FeinberG, Doing and Deserving: Essays in the Theory of Responsibility 98 (1970). Moreover, it is ludicrous to talk of "rehabilitating" someone who disposes of his garbage improperly or who fails to close his bar on time, or of "incapacitating" a dangerous offender of the Weights and Measures Act.

What, then, are these "sanctions?" They are devices to facilitate the regulation, rather than the prohibition, of certain activities. When a legislature enacts a homicide statute, its purpose is to protect the sanctity of life by imposing severe sanctions for unlawful killing. When it enacts a statute delegating to an agency the power to formulate a sanitation code backed by "penal" sanctions, it is doing something altogether different. The legislature is no longer engaged in prohibition, it is engaged in regulation. I realize that pursuant to the regulation of an area certain activities will be forbidden by the agency's rules, and a violation of these rules may be "criminalized." There is nonetheless a crucial distinction between the purposes of the two types of legislation. In the true criminal case, the activity is condemned and punished as violative of the community's mores; in the usual administrative case an activity is regulated without regard to the community's mores, and the only purpose of the sanction is to secure compliance with the agency's policies. When the condemnatory aspect of a sanction is absent, as is the case with administrative crimes, the sanction is no longer a criminal sanction in any meaningful sense. In short, the penalties imposed pursuant to administrative rules are not criminal sanctions at all. They are called "criminal" in an attempt to increase their deterrent efficacy, but the sine qua non of criminal penalties-"emphatic denunciation"-is absent. See Bell v. Department of Motor Vehicles, 6 Wash. App. 736, 496 P.2d 545 (1972).

Legislatures thus have tried to take advantage of the awe in which the criminal law is held, on the theory that by merely labeling something "criminal," people will be less likely to engage in the proscribed practice. Ironically, the overuse of the "criminal law" in this fashion has probably contributed more to an eradication of the fear and respect of the criminal law than it has contributed to coercing compliance with administrative rules.

The more widely the criminal conviction is used .... and the less clear the immorality of the behavior so sanctioned, the more likely would it appear that the criminal conviction will not only fail to attain the immediate purpose of its 
normally a technical expertise, such as in the classification of drugs by characteristics ${ }^{\mathbf{1 3 9}}$ or the determination of standards for

use but will degenerate in effectiveness for other purposes as well.

Kadish, Some Observations on the Use of Criminal Sanctions in Enforcing Economic Regulations, $30 \mathrm{U}$. CHI. L. REv. 423, 446 (1963). This, of course, is just one aspect of the general problem of overcriminalization. See Kadish, The Crises of Overcriminalization, 374 ANNALS 157 (1967).

More importantly, there is, or ought to be, more to the criminalization process than mere labeling. This point has been overlooked in much of recent scholarship. Thus, Professor Herbert Packer has written that "the definition of crime is inescapably tautological. Crime is whatever is formally and authoritatively described as criminal." $H$. Packer, The Limits of the Criminal Sanction 18 (1968). Even such an eminent scholar as H.L.A. Hart has said that "certain kinds of action [are] forbidden by law and so made crimes ... [t]o announce to society that these actions are not to be done and to secure that fewer of them are done." H.L.A. HART, Prolegomenon to the Principles of Punishment, in Punishment and Responsibility 6 (1968). Unfortunately, such a definition "tells us nothing about what the content of a law of crimes is or ought to be." $\mathrm{H}$. PACKer, supra, at 18.

The emptiness of the definition demonstrates its inaccuracy-there is more to the criminalization process than mere labeling. This becomes clear when one realizes that the criminal law-as distinguished from the criminal sanction-is but one part of an extensive system of social controls. There are many types of "sanctioning devices" designed to accomplish myriad tasks. See R. Pound, supra note 28 , at 1-35. The role of the criminal law in this scheme is to isolate and to condemn publicly acts that are nearly "universally disapproved of by members of . . society." H. Mannheim, Criminal Justice and Social Reconstruction 167 (1946) (quoting Emile Durkheim). Cf. Andenaes, General Prevention Revisited: Research and Policy Implications, 66 J. CRIM. L.C. \& P.C. 338, 341 (1975). Moreover, the strong sense of disapproval normally stems from a shared perception that the act violates the society's sense of security.

The primary role of the sanction in this process is to confirm the validity of characterizing an act as criminal. The sanction thus acts as a limiting device. Only if we are so repulsed by an act that we are willing to impinge upon the actor's freedom in a significant way can the act be made "criminal."

Furthermore, if Packer and Hart are correct in asserting that criminalization is merely a labeling process, that does not, as they realize, indicate what acts should be so labeled. None of the traditional "justifications" for punishment-deterrence, retribution, rehabilitation, or incapacitation-conveys any information concerning what is to be deterred, etc. By starting with an empty definition of criminality and viewing the paramount issue as the justification of punishment, the most that can be accomplished is the criminalization of those things the punishment of which will serve a purported justification of punishment. Is not the tail then wagging the dog? Surely the criminal sanction is a subordinate part of the criminal law rather than the other way around. To criminalize because, for example, a particular act can be deterred is to miss the point. An act should be criminalized to reflect society's condemnation; deterrence is only a secondary consequence of the criminalization decision. $C f$. Junker, Criminalization and Criminogenesis, 19 U.C.L.A.L. Rev. 697 (1972); Kadish, More on Overcriminalization: $A$ Reply to Professor Junker, 19 U.C.L.A.L. REv. 719 (1972). A recognition of the proper role of the criminal law would keep it within sufficiently narrow bounds to prevent trivialization of the criminal sanction. See R. Pound, supra note 28, at 28 . For a discussion of other distinguishing traits of the "administrative crime," see Force, Administrative Adjudication of Traffic Violations Confronts the Doctrine of Separation of Powers, 49 TuL. L. REv. 84, 131-38 (1974).

${ }^{139}$ People v. Einhorn, 75 Misc. 2d 183, 346 N.Y.S.2d 986 (1973); State v. Grinstead, 206 S.E.2d 912 (W. Va. 1974). Contra, Howell v. State, 300 So. 2d 774 (Miss. 1974). 
weights and measures. ${ }^{140}$ For example, in the case of drug classification, ${ }^{141}$ where a legislature thoroughly describes a set of drugs by characteristics there is no reason not to allow the agency to make an initial determination of fact concerning the nature of a specific substance. Since a legislature could penalize possession or use of drugs by characteristic rather than by name, empowering an agency to determine which drugs have characteristics bringing them within the prohibition serves solely to clarify the law-a salutary effect, indeed. Moreover, a defendant could contest an agency's factual determination that a drug is within the statutory definition. The agency, then, is doing no more than creating a presumption or establishing a prima facie case with regard to the nature of the drug. These delegations in the drug area are as close as an agency gets to affecting the scope of the substantive criminal law enforced by the police. Yet as long as the courts maintain the requirement of a specific standard, and as long as agencies are not empowered to refrain from classifying drugs whose characteristics fit within the statutory standard, these agencies will not be authorized to affect the scope of the substantive criminal law.

The delegation of rulemaking authority to an agency thus will often be upheld where the subject matter requires a technical expertise. Delegation will also be upheld where another special attribute, the ability to spend vast amounts of time on relatively inconsequential matters, is required. Thus the mundane affairs of running sewers and airports can be delegated to an agency; ${ }^{142}$ legislative time is better spent on other matters.

The cases sustaining the delegations in the areas discussed above indicate the accuracy of Professor Jaffe's summation of the factors involved in the decision to uphold delegations of legislative power:

Power should be delegated, where there is agreement that a task must be performed and it cannot be effectively performed by the legislature without the assistance of a delegate or without an expenditure of time so great as to lead to the neglect of equally important business. Delegation is most commonly indicated where the relations to be regulated are highly technical or

${ }^{140}$ People v. DeSilva, 32 Mich. App. 707, 189 N.W.2d 362 (1971).

${ }^{141}$ See note 139 supra.

${ }_{142}$ See Commonwealth v. Diaz, 326 Mass. 525, 95 N.E.2d 666 (1950); People v. Blanchard, 288 N.Y. 145,42 N.E.2d 7 (1942). 
where their regulation requires a course of continuous decision. ${ }^{143}$

Neither of these characteristics is involved in the aspects of the criminalization process with which Davis and other substantive rulemaking advocates are concerned. ${ }^{144}$ A legislature does not need experts to tell it whether to criminalize possession of marijuana or to prohibit drinking in the park. In fact, there is no better body than the legislature, assuming it is representative of the populace, to do this task of criminalizing. Furthermore, these decisions to criminalize conduct are not trivial matters. Thus the two justifications for delegation of rulemaking power to agencies-the need for technical expertise and the repetitive, relatively trivial nature of the subject matter-are not applicable to those portions of the substantive criminal law Davis' police rulemaking is designed to affect.

Moreover, a finding by a court that the subject matter of a delegation meets the criteria discussed above is generally not sufficient to uphold the delegation; the courts often express a great reluctance to uphold these grants of power unless a reasonably precise standard is provided by the legislature. Thus, the Iowa Supreme Court found that the delegation of the broad power to promulgate "rules and regulations as desirable for the proper use and conservation of the resources of the state" was invalid for lack of a sufficiently definite standard. ${ }^{145}$ The Court required the legislature to make "an intelligible and complete declaration of policy which is definite in describing the subject to which it relates or to the field wherein it shall apply, and the character of regulation which is intended to be imposed . . ."146 Another example of this judicial concern for a precise stan-

143 L. JAFFE, supra note 110 , at 35-36.

144 As Herbert Wechsler has said:

Whatever views one holds about the penal law, no one will question its importance in society. This is the law on which men place their ultimate reliance for protection against all the deepest injuries that human conduct can inflict on individuals and institutions. By the same token, penal law governs the strongest force that we permit official agencies to bring to bear on individuals. Its promise as an instrument of safety is matched only by its power to destroy. If penal law is weak or ineffective, basic human interests are in jeopardy. If it is harsh or arbitrary in its impact, it works a gross injustice on those caught within its toils. The law that carries such responsibilities should surely be as rational and just as law can be. Nowhere in the entire legal field is more at stake for the community or for the individual.

Wechsler, The Challenge of a Model Penal Code, 65 Harv. L. Rev. 1097, 1098 (1952).

${ }^{145}$ State v. Vantrump, 224 Iowa 504, 509, 275 N.W. 569, 572 (1937).

146224 Iowa at 508,275 N.W. at 571. 
dard is State $v$. Grinstead, ${ }^{\mathbf{1 4 7}}$ where the court upheld a delegation granting the Board of Pharmacy "the right to expand the list of proscribed drugs by adding thereto substances developed and derived from barbituric acid, amphetamines or any other substance which the Board of Pharmacy after investigation has found and declared to be "habit forming because of its stimulant effect on the central nervous system." "148 In the same opinion, however, the court held a delegation of the power to add to the list drugs that the Board found to be "dangerous or habit forming" 149 too indefinite to pass muster. It thus appears that delegations of rulemaking powers backed by penal sanctions will more likely be upheld when precise legislative standards ${ }^{150}$ accompany the authorization. ${ }^{151}$

147206 S.E.2d 912 (W. Va. 1974).

${ }^{148} I d$. at 919 .

${ }^{149} \mathrm{Id}$.

${ }^{150}$ There are decisions that cannot be reconciled to my theory. In Cole v. Manning, 240 S.C. 260, 125 S.E.2d 621 (1962), the Supreme Court of South Carolina approved a delegation of powers to the Department of Corrections to determine the meaning of "contraband" in a statute that penalized bringing contraband into a prison, although the legislature promulgated no standards to guide the Director in this task. See also United States v. Ahmad, 347 F. Supp. 912 (M.D. Pa. 1972), modified sub nom. United States v. Berrigan, 482 F.2d 171 (3d Cir. 1973). In State v. Watts, 186 N.W.2d 611 (Iowa 1971), the Supreme Court of Iowa approved a statute penalizing the violation by a parolee of any Parole Board rule. Once again, there were no legislative standards. Both cases involved heavy penalties, and neither dealt with matters of little importance.

${ }^{151}$ Perhaps one reason for this rigorous standard is the relationship of delegation to the constitutional doctrine under which a statute may be found to be void for vagueness. Under the void for vagueness doctrine developed by the federal courts, a criminal statute is unconstitutionally vague if it fails to give "a person of ordinary intelligence fair notice that his contemplated conduct is forbidden by the statute." Papachristou v. City of Jacksonville, 405 U.S. 156, 162 (1972) (quoting United States v. Harriss, 347 U.S. $612,617(1954)$ ). The basis of the vagueness doctrine is that "[a] vague law impermissibly delegates basic policy matters to policemen, judges and juries for resolution on an ad hoc and subjective basis ... ." Grayned v. City of Rockford, 408 U.S. 104, 108-09. See Note, Vagueness Doctrine in the Federal Courts: A Focus on the Military, Prison, and Campus Contexts, 26 STAN. L. Rev. 855 (1974) [hereinafter cited as Vagueness]; Note, The Void-For-Vagueness Doctrine in the Supreme Court, 109 U. PA. L. REv. 67 (1960). In other words, when "a vague criminal statute ... shifts the lawmaking authority to the judiciary or the law's administrators ... the federal courts ... shift the lawmaking authority back where it belongs." Vagueness, supra, at 860 . See also Bonfield, supra note 90, at 413-21; Bickel, supra note 101, at 63; Givelber, supra note 28, at 98. Compare this treatment of indefinite criminal statutes to indefinite civil statutes; very broad and imprecise delegations of power to agencies have been upheld in the civil area. See note 115 supra \& accompanying text. In the criminal area, however, as a matter of constitutional interpretation, it is the statute, not the agency's interpretation of it, which must give a person of ordinary intelligence "fair notice" of its meaning, even though there is no reason why an agency could not give substantive content to a vague criminal statute as easily as to a vague civil statute. In short, the Supreme Court has recognized, through the vagueness doctrine, the importance of reserving the legislative power in criminal matters to the legislature. Occasionally a court sees this relationship between 
In sum, then, a few states like Mississippi prohibit the legislature from delegating to administrative agencies any power to effect the scope of the substantive criminal law. ${ }^{152}$ Even where such delegation is allowed, however, it is limited to areas requiring special expertise-such as economic or health regulation-or to areas where a course of continuous decision regarding relatively inconsequential matters is required. Decisions regarding the scope of the substantive criminal law that is enforced by the police rather than by regulatory agencies fit into neither category, and thus the conclusion is inescapable that the state courts would generally not uphold such legislation.

Davis' belief to the contrary rests largely on his assumption that the police are closely analogous to administrative agencies and should be dealt with accordingly. ${ }^{153}$ The crucial error permeating this view is a failure to perceive, or at least to acknowledge, the different roles of the typical administrative agency and the police. Administrative agencies are regulatory bodies created to supervise relationships within their jurisdictions. ${ }^{154}$ The police, on the other hand, are not instructed to regulate; their purpose ${ }^{\mathbf{1 5 5}}$ is to enforce prohibitions articulated by the legislature. We do not say to the police: "Here is the problem. Deal with it."156 We say: "Here is a detailed code. Enforce it." In short, the police perform a very different function from that of a regulatory agency.

The confusions that emanate from this beguiling analogy are evident in the following passage from another of substantive rulemaking's proponents:

Certainly there is no reason to expect that legislatures can be more effective with respect to the work of police than they were with respect to the task of the economic regulatory agency. The "administrative process" and administrative flexibility, expertise, and, most important, administrative responsibility are as necessary and as appropriate with respect to the regulation of

vagueness and improper delegation. See, e.g., People v. Fields, 391 Mich. 206, 216 N.W.2d 51 (1974); State v. Turner, 3 Ohio App. 2d 5, 209 N.E.2d 475 (1965); State v. Grinstead, 206 S.E.2d 12 (W. Va. 1974).

152 See notes 119-26 supra \& accompanying text.

153 See Police Discretion, supra note 14, at 107-12.

${ }^{154}$ L. JAFFE, supra note 110 , at 1-10, 35-36. I am oversimplifying the matter, but it is helpful to do so in order to show how a regulatory agency differs from the police.

${ }^{155}$ See id. This is again oversimplified.

${ }^{156}$ Discretionary Justice, supra note 5 , at 48. 
deviant social behavior as they are with respect to other governmental regulatory activity. This seems perfectly obvious. ${ }^{157}$

I suppose it is "perfectly obvious" that if the role of the police is "the regulation of deviant social behavior," then "there is no reason to expect" miracles from the legislature. The purpose of the police, however, is not regulation of deviant behavior; it is enforcement of legislative proscriptions. When the proper role of the police is kept in mind, the role of the legislature can be viewed in its proper perspective. It then becomes very reasonable indeed to expect, and even demand, that the legislature fulfill its responsibilities.

In any case, whether for policy reasons or because of the constitutional doctrines discussed in this Article, no state legislature has ever delegated to the police the power to promulgate rules affecting the scope of the substantive criminal law. To the contrary, many states have full enforcement statutes that explicitly deny the police the discretion not to enforce criminal laws. ${ }^{158}$ Thus, even if I am incorrect that no delegations to the police in this area would be upheld by the courts, it is still clear that the police have no present authority to engage in substantive rulemaking. Indeed, if the delegation cases in this area tell us anything, it is that the police have no authority to engage in substantive rulemaking without explicit legislative authorization accompanied by precise standards. This requirement of precise and explicit legislative standards demonstrates that, contrary to Davis' position, neither legislative acquiescence in selective enforcement nor legislative appropriations that are insufficient for full enforcement ${ }^{159}$ provide adequate authorization for the police to engage in substantive rulemaking, even if there were no full enforcement statutes.

\section{Separation of Powers Revisited}

The principles discussed above evoke the image of a legal system intent on reserving to the legislature the power to define criminality. There is scant divergence between theory and practice in this regard. ${ }^{160}$ This, of course, bodes ill for Davis' pro-

\footnotetext{
157 TASK Force REPORT, supra note 4, at 18.

${ }^{158}$ See notes $46-50$ supra \& accompanying text.

${ }^{159}$ See text accompanying notes 57-61 supra.

${ }^{160} \mathrm{But}$ see note 150 supra.
} 
posal; if only the legislature can modify the scope of the substantive criminal law, then obviously the police are precluded from doing so. ${ }^{161}$ Davis attempts to solve the problems ${ }^{162}$ posed by this particular manifestation of the separation of powers doctrine ${ }^{\mathbf{1 6 3}}$ by offering two further arguments that he believes establish the authority of the police to engage in substantive rulemaking.

Davis first argues that the legality of police rulemaking may be established in the following way:

Any executive, such as a superintendent of police, may give instructions to his subordinates, may call the instructions rules, may open them to public inspection, and in preparing them may follow appropriate rulemaking procedure. ... The present general orders and special orders of the ... police are largely in the na-

161 Davis not only believes that the police can engage in substantive rulemaking but also that the courts, and in particular the federal courts, can force them to do so. POLICE Discretion, supra note 14 , at 129-38. His reasoning is simple and to the point: "A court can simply say that due process so requires . . ." Id. 132. See also Amsterdam, supra note 19, at 814; McGowan, supra note 28, at 683; Wright, supra note 115 , at 592. The recent Supreme Court decision in Rizzo v. Goode, 96 S. Ct. 598 (1976), however, casts serious doubt on the validity of Davis' argument.

In Rizzo the district court, in what Davis called a "quite inspiring" opinion, Police Discretion, supra note 14, at 130, ordered the Philadelphia police "to formulate and submit to [the] Court for approval, a comprehensive program for dealing adequately with civilian complaints alleging police misconduct." Council of Organizations on Philadelphia Police Accountability and Responsibility v. Rizzo, 357 F. Supp. 1289, 1321 (E.D. Pa. 1973), aff'd sub nom. Goode v. Rizzo, 506 F.2d 542 (3d Cir. 1974), rev'd, 96 S. Ct. 598 (1976).

In reversing, the Supreme Court stated that the district court opinion failed to account for the

important considerations of federalism . . . weighing against it. . . . Contrary to the District Court's flat pronouncement that a federal court's legal power to "supervise the functioning of the police department . . . is firmly established," it is the foregoing cases and principles that must govern consideration of the type of injunctive relief granted here. When it injected itself by injunctive decree into the internal disciplinary affairs of this state agency, the District Court departed from these precepts.

$96 \mathrm{~S}$. Ct. at $607-09$. What this opinion suggests is that only upon a very strong showing will the federal courts be permitted to impose a detailed rulemaking requirement on a state agency.

${ }_{162}$ Davis does suggest some awareness of the problems of his approach. See Potice DisCRETION, supra note 14 , at 110.

${ }^{163}$ For broader and more generalized treatments of separation of powers, see A. Vanderbilt, The Doctrine of Separation of Powers and its Present Day SigNificance (1953); M. Vile, Constitutionalism and the Separation of Powers (1967); Sharp, The Classical American Doctrine of "The Separation of Powers," 2 U. CHI. L. REv. 385 (1935). For general discussions of the relationship of separation of powers to administrative law, see Cheadle, The Delegation of Legislative Functions, 27 YALE L.J. 892 (1918); Parker, Separation of Powers Revisited: Its Meaning to Administrative Law, 49 MrCH. L. Rev. 1009 (1951). 
ture of rules, and they can be expanded to cover enforcement policy. ${ }^{164}$

I follow this all the way to the last "and." Apparently Davis is arguing that a rule is a rule, and if you can write one you can write them all. Surely that is incorrect. I agree that the police can, indeed should, formulate policies on a large variety of topics, ${ }^{165}$ but that does not mean that the police have unlimited power to write rules on anything that attracts their attention. Whether the police have the power to nullify criminal statutes through rulemaking is simply not answered by the fact that police superintendents can, for example, order their men to wear uniforms; I hardly think I need elaborate on the difference between a rule prescribing uniforms ${ }^{166}$ and one immunizing conduct made criminal by the legislature. Davis fails to consider the distinction between the legitimacy of a practice-in this case rulemaking-and the legitimate scope of that practice. ${ }^{167}$ Police rulemaking is acceptable if it is limited to matters that the police are authorized to decide. We have, however, reserved to the legislature decisionmaking that concerns the scope of the substantive criminal law.

Secondly, Davis argues that substantive rulemaking is desirable from a policy standpoint; he sees it as the only way to cut back our overly broad criminal law. ${ }^{168} \mathrm{He}$ would prefer that the legislature revise the criminal law; but, since he does not "expect

${ }^{164}$ Police Discretion, supra note 14 , at $110-11$. He supports his argument by describing what he perceives to be a trend in the United States towards the "judicial relinquishment of statutory standards as long as the administrative standards are adequate." Id. 112 (emphasis deleted). He cites only one example of this trend that has anything to do with the criminal law, People v. Fields, 391 Mich. 206, 216 N.W.2d 51 (1974), and describes it as being "the law everywhere except for the fact that most judges of most courts do not yet know that that is what they are going to hold when the problem comes to them." Id. Davis, however, appears to have misread the Fields opinion; the dissent, rather than the majority, supports his position. The court in Fields struck down a state statute on the grounds that it lacked sufficient standards and thus conferred too much discretion on the Michigan juvenile court judges. The court did so in the face of a lengthy dissent by Justice Levine who felt that the majority overemphasized the importance of statutory standards.

165 See note 19 supra.

${ }^{166}$ Such a rule is not objectionable. See, e.g., N.Y. Exec. LAw $\S 212$ (McKinney 1972). See also Kelly v. Johnson, 96 S. Ct. 1440 (1976) (upholding hair length regulations promulgated by a police commissioner).

${ }^{167} \mathrm{Cf}$. Wright, supra note 115 , at 576-77.

168 For discussions of our "overly broad criminal law," see H. Packer, supra note 138; Kadish, Some Observations on the Use of Criminal Sanctions in Enforcing Economic Regulations, 30 U. ChI. L. REv. 423 (1963). See also N. Morris \& G. Hawkins, ThE Honest Politician's Guide to Crime Control (1970). 
that," 169 he believes that the police must do the job instead. ${ }^{170} \mathrm{I}$ share Davis' concern with the proliferation of criminal offenses, but I do not think that he has provided an acceptable solution to the problem. Instead, his proposal undercuts the two major legislative values protected by the separation of powers doctrine: the maintenance of a popularly responsive lawmaking body, and the aroidance of an overconcentration of power in one branch of government.

With regard to the first of these values, one of the purposes of vesting the legislative power in a popularly elected body is that such a scheme "keeps the law-making power closer to the people and lines of responsibility between those who make and those who are subject to the laws direct and immediate. . . . If people do not like the laws that are made, they can tell whom to vote out of office." repealed or modified they can also tell "whom to vote out of office." Davis' proposal, however, would reduce the power of the people over the legislative process. Because the police generally are not elected, a determination by the police to nullify a particular statute often would be effectively insulated from popular review. ${ }^{172}$

This might not be so troublesome if there were general agreement regarding the laws that should be modified or repealed. Unfortunately there is not. It is true that part of the reason laws stay on the books is because of legislative inertia and neglect; ${ }^{173}$ some desuetudinal statutes probably do not represent the majority will, or at least would not be passed today. ${ }^{174}$ As a policy matter there might, therefore, be some merit to Davis' proposal if we could be certain that the police would modify or repeal only those laws that were opposed by an overwhelming majority of the population. In a situation in which the legislative

${ }^{169}$ Police Discretion, supra note 14 , at 67 . See also id. 79, 93-94, 156.

${ }^{170}$ Id. 67, 79, 93-94, 156.

$171 \mathrm{~J}$. Sutherland, Statutes and Statutory Construction $\$ 4.03$, at 73 (Sands ed., 4th ed. 1972). See also Wright, supra note 115 , at 585 ("The whole reason we have broadly based representative assemblies is to require some degree of public consensus before governmental action occurs.").

172 Davis would probably argue that his proposal calls for community input. But see notes $176-77$ infra \& accompanying text.

173 "The Anglo-Saxon sheds statutes which grow obsolete and obnoxious the same as a snake sheds his skin. He has seldom bothered to repeal them, as every one acquainted with the history of laws very well knows. No citizen any longer makes a complaint under them, and thus they become dead letter laws." People v. Hesterberg, 43 Misc. 510, 513, 89 N.Y.S. 498,500 (1904).

${ }^{174}$ See Bickel, Forward: The Passive Virtues, 75 Harv. L. Rev. 40, 63 (1961). 
process fails and a small minority prevents passage of popular reform, it is superficially appealing to allow another branch of government to repeal the unpopular statute. The problem with this approach is that the police are much less likely to be responsive to the popular will than is the legislature; indeed, our form of government is based on that assumption. Moreover, the phenomenon of laws remaining on the books is just as attributable, if not more so, to the fact that there is invariably significant sentiment opposing repeal. ${ }^{175}$ Viewed in this way, Davis' proposal becomes little more than a means of circumventing the popular sentiment impeding what he may view as the progress of the law. It is also a means of subverting popular domination of the legislative process, and consequently it would facilitate the imposition of a minority view of the proper scope of the criminal law. As Judge J. Skelly Wright has observed: "An argument for letting the experts decide when the people's representatives are uncertain or cannot agree is an argument for paternalism and against democracy." 176

To be sure, Davis does call for open rulemaking with community participation. It is, however, unclear how community input is to be utilized. ${ }^{177}$ Consider the two possibilities: If any significant opposition to a proposed police rule would suffice to prevent its promulgation, then Davis' proposal is futile, for there will be such opposition almost invariably. Yet if the police are permitted to ignore significant opposition and fashion their rule "in the best interests of society," Davis' proposal would not differ from our present system, except that popular control over the

${ }^{175}$ See, e.g., Rodgers \& Rodgers, supra note 93, at 8 n.48. Each of Davis' suggestions for rules that the police ought to write is susceptible to this criticism. See text accompanying note 88 supra; note 179 infra. In fact, practically every commentator who makes an argument similar to Davis' neglects to list those statutes he would like to see abrogated by police rulemaking. See, e.g., Abernathy, Police Discretion and Equal Protection, 14 S.C.L.Q. 472 (1962); Igleburger \& Schubert, supra note 12. The few who, like Davis, suggest laws that should be modified or repealed merely demonstrate the lack of agreement with respect to any particular statute. Consider, for example, Kadish, Legal Norm and Discretion in the Police Sentencing Process, 75 Harv. L. Rev. 904 (1962). In his list of situations in which "the need for some kind of amelioration [of the criminal law's harshness] is plain," he includes the case of a wife arrested for "falsely reporting a felony, where under interrogation she admits to claiming she was raped in order to conceal her infidelity from her husband." Id. 913. I can think of fewer cases more deserving of harsh punishment than one in which someone exposes another to liability for a serious crime simply to save the accuser some inconvenience or embarrassment. See generally McGowan, supra note 28.

${ }_{176}$ Wright, supra note 115 , at 585 (footnote omitted).

${ }^{177}$ Police Discretion, supra note 14, at 103-07. 
process would be diminished. ${ }^{178}$ Such a result should not be permitted without the strongest justifications, justifications which, in my judgment, have not been provided. ${ }^{179}$

The proposal that police engage in substantive rulemaking is also inconsistent with the second major purpose of separation of powers-restricting the concentration of power in any one branch of government. Governmental power is diffused by the

${ }^{178}$ Davis suggests that his argument could only be rejected by those not in favor of democracy. Id. 70, 72, 115-16. Police rulemaking, however, is actually an anti-democratic measure. See text accompanying note 176 supra.

${ }^{179}$ Davis argues that "[o]ur legislative bodies probably lack the capacity to legislate the needed refinement" of our criminal law. POLICE. DisCReTION, supra note 14, at 67; see Goldstein, supra note 12, at 1130 . Yet the rules Davis suggests that the police should promulgate, see Police Discretion, supra note 14, at 91, 142, 157, 159-60, are simple enough that even our most incompetent legislators could understand and propose them, if they so desired. Perhaps it is legislative failure to enact Davis' conception of an appropriate criminal law, rather than an inability "to legislate the needed refinements," that is actually troubling him.

Davis also suggests that allowing the police to engage in rulemaking would spur legislative action. Id. 116-17. He may be right, but such an outcome is far from clear. "The enforcement authorities . . . will sometimes mitigate the harsh effects of statutes that they believe to be overly broad. . . . It would not be so bad if this kind of differential enforcement were the harbinger of law reform. More often it is simply the substitute." H. PACker, supra note 138, at 291.

A final problem with Davis' desire to modify our legislative process concerns the purpose of the criminal law. Davis apparently thinks that one of the most significant goals of the criminal law is to "fully enforce" whatever statutes are enacted. Thus, he says that "in an ideal world, the criminal legislation would be tailored to what is practically enforceable," and that "[i]nstead of the system we have, I would much prefer ... a system in which the legislatures would make careful inquiries into what can or cannot be enforced and tailor their statutes accordingly." POLICE Discretion, supra note 14 , at 67,94 . This paradigm of the ideal criminal law presents several difficulties.

In the first place, Davis does not tell us what it means to "enforce" a statute. If he means that the criminal law should prohibit only those acts that we can eliminate from society, then there may be little that we would be able to criminalize. On the other hand, if he means that we should only criminalize those acts that involve a high probability that the offender will be discovered-say, $80 \%$-we could criminalize murder (and perhaps kidnapping), but nothing else. See 1974 FBI UNIFORM CrIME REPORTS 10-42.

The point is, of course, that rate of capture or conviction is only one factor that must be taken into account in the decision to criminalize. If it were the only factor, not only would larceny and burglary have to be removed from our statute books, see id., but also such frequently unreported crimes as childbeating and extortion.

More fundamentally, in his concern with enforceability Davis fails to consider other important aspects of the criminal law. "The crux of the matter is that the criminal law is not just another governmental program serving a defined functional policy, which may be freely abolished when times change or its programmatic effectiveness becomes doubtful." Rosett, Discretion, Severity, and Legality in Criminal Justice, 46 S. CAL. L. REv, 12,33 (1972). In other words, Davis fails to appreciate "the symbolic richness of the criminal process." H. PACKER, supra note 138, at 44; see note 138 supra. Compare PolicE Discretion, supra note 14 , at 74 , with Kadish, supra note 175 , at $914-15$ and Note, 75 Colum. L. Rev. 130, 141 (1975). Compare Police Discretion, supra note 14, at 67, 94, with Breitel, supra note 11, at 428, 430 and Hall, supra note 4, at 135. 
creation of distinct branches of government and a system of checks and balances. Since any particular branch of government needs the support of the others, governmental encroachment upon liberties is made more difficult, and, hopefully, freedom is preserved. ${ }^{180}$

This concern is particularly acute in the criminal law. As Professor Bonfield has commented, "the perpetuation of the dichotomy between those empowered to formulate and those empowered to apply the criminal law has long been a vital part of our tradition. Further than this, it has assured more than an insignificant quantum of safety for our liberties."181 Davis' proposal is inconsistent with the maintenance of this dichotomy because it would transfer a portion of the power to modify and repeal statutes from the legislative to the executive branch. Moreover, it would sacrifice these values in return for some rather dubious benefits.

The benefit that Davis believes will result from substantive rulemaking by the police is that certain overly broad statutes will be trimmed. ${ }^{182}$ Yet nothing guarantees such a result. What if the police do not exercise this power as Davis would like? What if for "the rough approximation of community values that emerges from the legislative process there is substituted the personal and ... idiosyncratic values of the law enforcer"? ${ }^{183}$ For example,

${ }^{180}$ See C. Montes Quieu, The Spirit of Laws (J. Nugent transl. 1949). See also VANDERBILT, supra note 163, at 4; Cheadle, supra note I63, at 894-95. For a discussion of the development of the separation of powers theory, see G. SABINE, A History of Political Theory 558-60, 694-99 (3d ed. 1961). See also note 163 supra; Ala. Const. art. III, $\$ 43$ (separation of powers is instituted "to the end that it may be a government of laws and not of men").

${ }^{181}$ Bonfield, supra note 90 , at 423 (footnote omitted). See also Sharp, supra note 163 at 386 .

${ }^{182}$ Davis also believes that by bringing the selective enforcement decision out into the open through rulemaking, the danger of arbitrary decisionmaking by individual police officers will be decreased. POLICE Discretion, supra note 14, at 114-17.

Although reducing arbitrary decisionmaking is a laudable goal, it is far from clear that substantive rulemaking will have the desired effect. Another area where rulemaking has been tried-plea bargaining-might lead us to pause before we adopt substantive rulemaking for such a reason. The A.B.A. Standards Relating to Pleas of Guilty, an attempt to structure and control the exercise of discretion with respect to plea bargains, has succeeded only in demonstrating the truth of the National Advisory Commission's belief that "rationality cannot be brought into the system by raising the visibility of the plea negotiation process and structuring the making of the administrative decisions in it." National advisory Commission on Criminal Justice Standards and Goals, Courts 48 (1973). See, e.g., People v. Earegood, 12 Mich. App. 256, 162 N.W.2d 802 (1968), modified on other grounds, 383 Mich. 82, 173 N.W.2d 205 (1970). See also Jaffe, supra note 30, at 777; Rosett, supra note 179, at 13-19; note 206 infra \& accompanying text.

${ }^{183}$ H. PACKER, supra note 138, at 290. 
what if the police do not cut back the scope of the marijuana law, but instead promulgate a rule that they will not enforce the assault statutes against anyone who attacks University of Chicago law professors who write monographs critical of the Chicago police ${ }^{184}$ Perhaps the courts would nullify the rule as an improper exercise of police authority, but what guarantees this result? If the police are permitted "to substitute their own value preferences for that of the legislature,"185 how are the courts to determine that an improper substitution has been made? What is there, in other words, to make one suppose that the executive, checked by an unchecked judiciary, will be a more satisfactory articulator of policy than is the legislature? Very little, I should think.

As Justice Holmes once stated, "where to draw the line . . . is the question in pretty much everything worth arguing in the law." 186 We have drawn a line with respect to the power to legislate criminal statutes-the power resides in the legislature. Davis may not like where the line is drawn, but more is required to demonstrate the wisdom of placing it elsewhere than mere speculation concerning a potential benefit that might accrue. Absent from his proposal is any discussion of how this rulemaking power is to be limited to his conception of its proper scope. In short, the argument for substantive rulemaking not only ignores the problems posed for it by our theories of government, but it also fails to make a cogent case that the benefits that it anticipates will be achieved.

${ }^{184}$ Davis' book purports to be largely an empirical study of the Chicago police. Preface to Police Discretion, supra note 14, at iii. The empirical information was gathered through approximately 300 interviews with police officers. Id. 175. Davis, however, does not make a systematic presentation of what was said in the interviews; instead, the reader only finds Davis' impressions of what transpired. See id. 173-76. This is troublesome because throughout the book Davis talks of "facts." For example, Davis states in his preface that "[t]he main facts about selective enforcement in the Chicago police department are clear ...." Preface to id. iii. Furthermore, Davis never accounts for the possibility that what was said during these interviews might not be accurate representations of reality. This is disturbing because on the basis of these interviews Davis levels some serious charges at the police. He suggests that most arrests for disorderly conduct in Chicago are without probable cause and are for purposes of harassment, id. 14-15, and also says that many officers believe "all society is divided into two classes of people, the 'kinky' (criminal) class and the law-abiding class. The officers can tell which are which by physical characteristics and appearance . . . Id. 18. Such accusations should not be made without a more substantial basis. But see id. 19-20.

${ }^{185}$ Remington \& Rosenblum, supra note 3 , at 489 ("The danger is that agencies will assume a license to substitute their own value preferences for that of the legislature").

${ }^{186}$ Kamisar, Equal Justice in the Gatehouses and Mansions of American Criminal Procedure, in Criminal Justice in our Time 73-74 (A. Howard ed. 1965) (quoting Irwin v. Gavit, 268 U.S. 161, 168 (1925) (Holmes, J.)). 
These objections to substantive rulemaking might be much less troubling were I not convinced that the substantive rulemaking proposal would not accomplish its goals even if it were sufficiently limited. I share Davis' desire to minimize arbitrary decisionmaking by the police, but it is unlikely that the police would presently engage in substantive rulemaking on any significant scale; and even if they did, the practical effects would be minimal.

In the first place, Davis fails to consider the strong resistance his proposal is likely to encounter from the very group responsible for its implementation-the top officials in the police departments. Although Davis believes that the scope of certain statutes should be restricted, the concern of most police officials is precisely the opposite:

Broadly-stated laws are, after all, one of the lesser concerns of the police. Most attention of law enforcement officers in recent years has focused upon legal provisions which are too narrow. The average police official is not very concerned about having the authority to enforce adultery statutes and not having the manpower or the community support necessary to do so. $\mathrm{He}$ is much more concerned because of his inability to attack organized crime effectively. And there may be an occasion upon which he can use an obscure or otherwise unenforced law to launch an oblique attack against a situation or activity which he feels warrants action on his part. His attitude is often that the law should be left on the books; it may come in handy sometime. Why impose self-limitations on police authority beyond those established by the legislature? ${ }^{187}$

Moreover, the line officer may perceive substantive rulemaking as simply creating more technicalities that will make his job more difficult. Consequently, many police officials may resist the institution of the procedure because of a fear that it would result in a decline in department morale. The vehement reaction of law enforcement agencies to constitutional decisions that were viewed as "handcuffing the police" is all too well known;"188 I

${ }^{187}$ Goldstein, Police Discretion: The Ideal Versus the Real, 23 PuB. AD. REv. 140, 144 (1963). See also TASK FORCE REPORT, supra note 4, at 16-18; Arnold, Law EnforcementAn Attempt at Social Dissection, 42 YALE L.J. 1, 17-18 (1932).

${ }^{188}$ See, e.g., Kamisar, On the Tactics of Police-Prosecution Oriented Critics of the Courts, 49 Cornell L. Rev. 436 (1964); JuRis Doctor, Oct. 1975, at 12 (remarks of F.B.I. Director Clarence Kelly). 
doubt that the police command will be very eager to engage in what may be viewed as an extension of that process. ${ }^{189}$ Furthermore, as a ranking police official has pointed out:

[I]f a written document is desired, the preparation of criteria for the exercise of discretion requires an expert draftsman-one more skilled than the legislative draftsman who may have tried and failed. Is it any wonder that the typical reaction of the police administrator . . . is likely to be: "It isn't worth the trouble!"?190

Finally, even if police officials could be convinced to use their rulemaking powers, it is uncertain whether police behavior would be affected. Davis states that "rulemaking can reach all police activities," 191 but he does not attempt to substantiate this assertion. He consequently fails to acknowledge

the high degree of solidarity displayed by most officers. .. . Since police officers have developed unified and mutually supportive means of reacting to common problems, their superiors often encounter difficulty in attempting to gain firm control of the department. ... Since many patrolmen accept the guidance of fellow officers rather than the rules promulgated by their superiors, the cohesion of police forces is a major obstacle to the imposition of effective restrictions on police conduct. ${ }^{192}$

189 See J. Skolnick, Justice Without Trial 224-27 (1966).

${ }^{190}$ Goldstein, supra note 187, at 144. The police would resist Davis' proposal for other reasons as well. See generally Caplan, supra note 12, at 505; Goldstein, supra note 187, at 144; Goldstein, Administrative Problems in Controlling the Exercise of Police Authority, 58 J. CRIM. L.C. \& P.S. 160 (1967).

Related to the expert draftsman problem is the belief that rulemaking will allow the police to bring their peculiar expertise to the process. Police Discretion, supra note 14, at 113-14; see Goldstein, supra note 19, at 23-25. The idea is that the police know best what is enforceable; however, that knowledge is of only limited value in the criminalization process. See note 179 supra. As Mr. John Quinn has observed in a related context:

An argument for rulemaking based on the benefits of the injection of police expertise into the decisionmaking process is not persuasive. Because of the highly political or value oriented nature of ... [many of the] issues, technical or practical expertise is of ancillary utility at best and could actually be harmful if allowed to play a dominant role. Insofar as police expertise is useful in deciding legal issues it can be made available to the . . decisionmaker without administrative rulemaking simply by submitting a Brandeis brief . ..."

Quinn, The Effect of Police Rulemaking on the Scope of Fourth Amendment Rights, $52 \mathrm{~J}$. Urban L. 25, $27-28$ n.14 (1974). See also LaFave, Penal Code Revision: Considering the Problems and Practices of the Police, 45 Texas L. Rev. 434 (1967).

191 Police Discretion, supra note 14, at 118.

${ }^{192}$ Hahn, A Profile of Urban Police, 36 Law \& Contemp. Pros. 449, 453, 455 (1971). 
The foregoing suggests that, Davis' apparent assumptions to the contrary notwithstanding, ${ }^{193}$ the promulgation of substantive rules probably will not affect police behavior significantly. His proposal, therefore, only avoids the problem of police discretion, ${ }^{194}$ rather than mitigating it.

One final point should be made. Some of the arguments that I have advanced may appear inconsistent with one another. On the one hand, I have argued that substantive rulemaking should be rejected because it impinges too far upon the legislative domain; on the other hand, I have argued that the practical consequences of substantive rulemaking would most likely be negligible. One might reasonably wonder how substantive rulemaking would subvert one of our cherished institutions while at the same time have no practical effect. My response to this apparent inconsistency is twofold. First, merely because substantive rulemaking by the police would be ineffective does not make it more consistent with the constitutional principles discussed in this article or more desirable from a policy standpoint. If substantive rulemaking is theoretically objectionable both as a constitutional and policy matter, it is no argument to say that the concept should be adopted merely because it would be ineffective. On the other hand, substantive rulemaking's probable ineffectiveness is a reason for rejecting Davis' proposal. Moreover, although I seriously doubt that under present conditions our

See also E. Bittner, The Functions of the Police in Modern Society 63-71 (1970); W. Bopp, Police Administration: Selected Readings, 75-190 (1975); Goldstein, Who's in Charge Here?, 50 Pub. Management 304 (1968); Milner, Supreme Court Effectiveness and the Police Organization, 36 Law and Contemp. Prob. 467 (1971); Schwartz, supra note 19, at 449; Comment, Socio-legal Aspects of Racially Motivated Police Misconduct, 1971 Duke L.J. 751. But see Balch, The Police Personality: Fact Or Fiction?, 63 J. CrIM. L.C. \& P.S. 106 (1972); Wilson \& Alprin, supra note 19. This resistance to supervision is exacerbated by the difficulty of supervision resulting from the low visibility of much police activity. Goldstein, supra note 4, at 552-54; LaFave, The Police and Nonenforcement of the Law (pt. 2), 1962 Wis. L. REv. 179, 180.

193 "Students of legal change too often approach their subject matter with an implicit belief that legal rules will have some significant effect and that noncompliance is aberrant." Milner, supra note 192, at 485 .

${ }^{194}$ Davis also fails to examine the question of cost. Most police forces currently lack the expertise needed to draft meaningful rules, Caplan, supra note 12, at 512; Goldstein, supra note 187, at 144; see TASK FORCE REPORT, supra note 4, at 37, and the money to obtain the requisite expertise would have to be appropriated. Moreover, Davis believes that rulemaking should be based on "systematic studies by staffs of qualified specialists or on investigations like those conducted by our best administrative agencies and legislative committees." Davis, supra note 23 , at 704 . I seriously doubt that any state would allocate sufficient sums of money to permit the police to duplicate or (depending on how you view it) subvert the legislative process. 
police forces would accept the invitation to engage in substantive rulemaking on a significant scale, I am less confident of my ability to predict the future. The exercise of this power may become attractive to the police in the future for some unknown reason, or the police may choose to exercise it in a way not contemplated by Davis or anyone else. This possibility is facilitated by the fact that the power Davis wishes the police to exercise is not specifically limited. In fact, it is Davis himself who has so often and so well pointed out ${ }^{195}$ that just such a power tends to be abused. It may be argued that this problem could be avoided if the legislature gave the police a limited grant of authority to restrict the scope of certain laws. In that case, however, there would be no good reason why the legislature could not go one step further and simply restrict those laws itself.

In sum, Davis has not met his burden. He has little support in precedent or authority, and the policy considerations he advances are insufficient to justify sacrificing separation of powers in the criminal law to the extent he desires. While Davis has articulated what some perceive as a cost in our system of representative democracy, ${ }^{196}$ he has not demonstrated that his suggestion would be any less costly. Moreover, he has also failed to demonstrate that the cost of our present system is not well worth its tendency to restrict the executive's arrogation of power, or that " $[r]$ esponsibility for the enactment, amendment, and repeal of the criminal laws [should] . . . be abandoned to the whim of each police ... department [rather than] retained where it belongs in a democracy - with elected representatives."197

195 See, e.g., Discretionary Justice, supra note 5, at 52-54.

${ }^{196}$ See, e.g., Wright, supra note 115 , at 585 .

${ }^{197}$ Goldstein, supra note 4, at 587. If editorials are any indication of public sentiment, Davis would also have a difficult time convincing the general populace of the worth of his proposal. See, e.g., B. Grossman, supra note 1, at 95 (quoting Editorial, Shall Police Chiefs Decide Which Laws to Enforce?, Capital Times (Madison, Wis.), Sept. 6, 1961). See also Editorial, Usery's Statement and Respect for Law, Buffalo Courier Express, Dec. 16, 1975, at 14, col. 1; Editorial, Enforce 'Blue Laws' Uniformly, Buffalo Courier Express, Dec. 3, 1975, at 30, col. 1. This resistance is well-founded. As Justice Frankfurter warned:

Not so long ago it was fashionable to find our system of checks and balances obstructive to effective government. It was easy to ridicule that system as outmoded-too easy. . . . The accretion of dangerous power does not come in a day. It does come, however slowly, from the generative force of unchecked disregard of the restrictions that fence in even the most disinterested assertion of authority.

Youngstown Sheet \& Tube Co. v. Sawyer, 343 U.S. 579, 593-94 (1952) (Frankfurter, J., concurring). 


\section{The Legal Control of Police Behavior}

Thus far I have only articulated the weaknesses of one proposed method of controlling police behavior. That alone is an inadequate treatment of this troublesome area. Unless we are willing to let the police continue deciding what statutes to enforce and how and when to enforce them, ${ }^{198}$ or unless we are willing to rest on the assertion that there is no reason for the police to exercise any discretion, ${ }^{199}$ there still remains the problem of fashioning effective legal controls to restrict "lawless" police discretion. ${ }^{200}$

The most effective restriction on the scope of police discretion can be achieved by controlling the allocation of police resources. ${ }^{201}$ Although there may be many explanations for the existence of police discretion, a major reason is certainly the insufficient resources provided by our legislatures. ${ }^{202}$ As Judge

${ }^{198}$ One advantage of rejecting any attempt to regulate police conduct is that it no longer would be "tactless [or] . . . even hazardous for a student of police administration to open an interview with a police chief with a hearty, "Well, Chief, what laws are you enforcing this week?' " Abernathy, supra note 175, at 472 .

199 "Explanations can be given for not fully enforcing the law; for example, limitations on time and personnel, to include inadequate investigative techniques (budgetary considerations), ambiguity of criminal statutes, and pressures from within and without on a human institution are but a few. None seems persuasive." Cox, Discretion- $A$ Twentieth-Century Mutation, 28 OKLA. L. REv. 311, 316 (1975).

${ }^{200}$ One commentator apparently believes that society is on the horns of a dilemma: "[T] he courts must recognize the power of the police to narrow the legislative proscription by selective enforcement in some cases-unless the police have the capacity to arrest and prosecute every violator of a statute. The police must have the discretion to select, on reasonable grounds, those violators who are to be arrested." Tieger, Police Discretion and Discriminatory Enforcement, 1971 Duke L.J. 717, 731. There are, however, other choices. See text accompanying notes 201-06 infra.

${ }^{201}$ Actually, the most effective way to restrict police discretion would be to revise the criminal law to eliminate vague and overly broad statutes. See Breitel, supra note 11, at 432-33; Israel, The Process of Penal Law Reform-A Look at the Proposed Michigan Revised Criminal Code, 14 WAYNe L. Rev. 772, 813-14 (1968). This revision, however, is not likely to occur on any great scale.

${ }^{202}$ A striking example of this is found in W. LAFAvE, supra note 6 , at $71 \mathrm{n} .33$ (quoting California State Department of Education, California Police Officers' Training Bulletin No. 71, Police Supervisory Control 26-27 (1957)):

A study of traffic violations at Rose and Grove Streets, Berkeley, California, revealed that if conditions at other intersections were similar, three million violations of traffic regulations were occurring daily in Berkeley and that it would take more than fourteen thousand traffic officers to enforce the traffic laws in that city. With hundreds of thousands of federal, state and municipal laws to be enforced, it becomes obvious that considerable discretion must be exercised in the direction of the enforcement policy.

In 1973, Berkeley's entire police force numbered 233. 1973 FBI UNIForm CRImE REPORTS 178. See also W. LAFAVE, supra note 6, at 102-24; Goldstein, supra note 4, at 560-61; Goldstein, supra note 187, at 142-43; Goldstein, supra note 12, at 1125; Hall, supra note 4, at 149; Igleburger \& Schubert, supra note 12, at 307; Note, Discriminatory Law Enforcement and Equal Protection from the Law, 59 YALE L.J. 354, 357 (1950). 
Charles Breitel has observed, "A society can only pay so much for protection. It cannot put a policeman on every street corner."203 As a result of our unwillingness to overpolice ourselves, "forces of crime control are deployed. And the deployment changes from time to time, to meet conditions or public pressures. The discretion of deployment decides more than anything else who or what crimes shall be prosecuted." 204 Consequently, by exercising control over the "discretion of deployment" a jursidiction could greatly curtail the scope of a police department's discretionary authority.

This control could be achieved in several different ways, but all would involve the creation of a visible, and reviewable, decisionmaking process. Should direct legislative input into the allocation decision be desired, it could be achieved through the budgetary process. The police could be required to forward a specific budget to the legislature for approval, or the legislature could, through its own hearing process, determine the appropriate allocation. ${ }^{205}$ Alternatively, the police could determine the appropriate allocation of resources through an administrative process. Their decision could then be reviewed by the courts according to a specified standard of review. ${ }^{206}$

Even without statutory authorization, the police probably possess an inherent power to allocate their resources pursuant to departmental priorities. ${ }^{207}$ This conclusion is suggested by the equal protection cases stemming from Yick Wo v. Hopkins. ${ }^{208}$ Cognizant of the fact that the police cannot possibly apprehend all violators of any criminal law, the courts have uniformly held that it is no defense to a criminal charge that there are others

${ }^{203}$ Breitel, supra note 11 , at 431 .

${ }^{204} I d$.

205 See D. Shoup \& S. Mehay, Program Budgeting for Urban Police Services With SPECIAL Reference to Los ANgeles (1972). See also Goldstein, supra note 4, at 576; Comment, Program Budgeting for Police Departments, 76 Yale L.J. 822 (1967).

${ }^{206}$ See Police Discretion, supra note 14, at 117-18. For a discussion of police resource allocation, and one means of accomplishing the task rationally, see Walton, "Selective Distribution" of Police Patrol Force (pts. 1, 2), 49 J. CRIM. L.C. \& P.S. 165, 379 (1958). See also Allocation of Patrol Manpower Resources in the St. Louis Police Department (1966); O. Wilson, Police Planning (2d ed. 1957). It is beyond the scope of this article to develop the details of any particular allocation scheme. Suffice it to say that attention must be given to such considerations as the determination of the appropriate factors to be taken into account and the mechanism for doing so, the proper issues to be dealt with, the method of review to be available, and the standard of review to be applied. See generally National Advisory Commission on Criminal Justice STANDARDS AND Goals, supra note 23, at 12-16.

${ }^{207}$ See, e.g., United States v. Wilson, 342 A.2d 27 (D.C. App. 1975).

208118 U.S. 356 (1886). 
against whom the statute has not been enforced. Instead, the defendant must show that he has been invidiously discriminated against. ${ }^{209}$ Implicit in this position is a recognition of the need for, and the power of, the police to make decisions regarding the allocation of their scarce resources. Thus, the courts do not ask whether all violators of a particular statute who could be apprehended have been; rather, they ask if the defendant has been selected on the basis of an improper motive. ${ }^{210}$

The only state case that involves an explicit police rule reducing the scope of a substantive statute is often read to mean that the police may not make reasonable allocation decisions. In Bargain City U.S.A., Inc. v. Dilworth, ${ }^{211}$ the court held that a police chief's decision, prompted by inadequate resources, to enforce the Sunday Blue Laws against only large retail establishments unconstitutionally discriminated against those businesses. Bargain City has often been compared with the Supreme Court decision in Moog Industries, Inc. v. F.T.C. ${ }^{212}$ upholding a cease and desist order of the F.T.C. against a single firm, even though other firms allegedly were similarly situated. A number of commentators, believing that Bargain City and Moog Industries are irreconcilable, have concluded that Bargain City is inconsistent with permitting the police to allocate resources. ${ }^{213}$ The cases, however, are not inconsistent.

Most commentators rely on a passage in Moog Industries in which the Court said that "the Commission alone is empowered to develop that enforcement policy best calculated to achieve the ends contemplated by Congress and to allocate its available

${ }^{209}$ See Givelber, supra note 28; Comment, The Right to Nondiscriminatory Enforcement of State Penal Laws, 61 Colum. L. Rev. 1103 (1961); Note, 55 Minn. L. Rev. 1234 (1971). See generally Y. Kamisar, W. LaFave \& J. Israel, Modern Criminal Procedure 840-61 (4th ed. 1974).

${ }_{210}$ This was originally thought to mean that the defendant must prove he was selected on the basis of such things as race, sex, or religion; however, there are now indications that the courts are beginning to broaden the criteria. See, e.g., United States v. Steele, 461 F.2d 1148 (9th Cir. 1972); United States v. Robinson, 311 F. Supp. 1063 (W.D. Mo. 1969); Murguia v. Municipal Court, 15 Cal. 3d 286, 540 P.2d 44, 124 Cal. Rptr. 204 (1975). For one of the few cases that explicitly recognizes the power of the police to allocate resources, see Gowan v. Smith, 157 Mich. 443, 122 N.W. 286 (1909). For an interesting discussion of this and other related issues, see Winston, On Treating Like Cases Alike, 62 CAL. L. Rev. 1 (1974).

21129 U.S.L.W. 2002 (Pa. C.P., Phila. County, June 10, 1960), injunction dissolved, No. 1411 (Pa. C.P., Phila. County, Sept. 13, 1961) (unreported), aff'd on other grounds, 407 Pa. 129, 179 A.2d 439 (1962).

212355 U.S. 411 (1958).

${ }^{213} \mathrm{See}$, e.g., W. LAFAvE, supra note 6, at 73; Abernathy, supra note 175, at 475-76; Remington, supra note 23, at 362-63. 
funds and personnel in such a way as to execute its policy efficiently and economically." 14 The Court, however, said much more than that. The quoted passage comes at the end of a long paragraph suggesting other conceivable justifications for the F.T.C.'s action. The Court noted that the petitioner simply may have been the first violator to be prosecuted, that the relevant industry may not have been clear, or that it may have been that no other firm was in fact "similarly situated." Thus, the allocation of resources issue was only one of several bases for the decision. More importantly, in Bargain City the police chief attempted to repeal a portion of the statute by rule, pleading lack of resources. In Moog Industries, on the other hand, there was no allegation that the F.T.C. was not prepared to move against other violators of the statute; it was only alleged that the F.T.C. had not yet done so. Because it was impossible to deal with all violators at once, the F.T.C. had to decide where to start.

This latter type of resource allocation differs qualitatively from that attempted in Bargain City. The contrast both reconciles the two cases and illustrates a limiting factor in a police department's power to allocate available resources. Although resources must be allocated, it is one thing to allocate them over the entire range of authority granted to an enforcement agency; it is quite another effectively to repeal part of that authority by institutionally refusing to exercise it. The importance of Bargain City is that it indicates that the police may not do indirectly through resource allocation what they are prohibited from doing directly through substantive rulemaking-effectively repeal criminal statutes. ${ }^{215}$

This does not mean that a police force must deploy its resources on the basis of anticipated offenses, regardless of severity. A police department need not, for example, put all its forces on traffic patrol merely because the department knows that many more traffic offenders will be apprehended by doing so. The department surely may decide to allocate some resources to other more serious crimes that are more difficult to combat. What the police may not do, however, is simply to refuse to enforce at all. ${ }^{216}$ Thus, when a complaint is filed, it should be

214355 U.S. at 413.

215 Of course, it may be difficult in some instances to draw the line between legitimate allocation and improper nonenforcement, and the courts will have to consider the circumstances of each case to determine whether particular resource allocation in fact results in nonenforcement.

${ }^{216} C f$. Goldstein, supra note 4, at 585-86; Goldstein, supra note 187 , at 141-42. For 
assigned to an investigator rather than ignored simply because that particular law is not being enforced. ${ }^{217}$

Of course, not all instances of nonenforcement are the result of deployment discretion, and the problem of individual police officers deciding when to invoke the criminal process remains. Not all such individual decisions involve the type of police discretion at issue in this Article. ${ }^{218}$ There will be many instances in which a decision not to invoke the criminal process, even

a statutory authorization of the power to allocate police forces, see OHIO REv. CodE ANN. \& 737.06 (Page 1976).

A few cases are inconsistent with my position. In Taylor v. City of Pine Bluff, 226 Ark. 309, 289 S.W.2d 679, cert. denied, 352 U.S. 894 (1956), the court held that enforcement agencies could make reasonable classifications that could have been made by the legislature. The Arkansas Supreme Court reaffirmed Taylor the following year. Hickinbotham v. State, 227 Ark. 1032, 303 S.W.2d 565 (1957). The only other case reaffirming this principle is City of Minneapolis v. Buschette, 240 N.W.2d 500, 506 (Minn. 1976).

Joseph Tieger cites four other cases which also deal with selective police enforcement of Sunday Blue Laws. Tieger, supra note 200, at 730-31 \& nn.59,61. One may infer that Tieger reads these cases as being in accord with Taylor; however, none of these cases specifically embrace the Taylor "legislative classification" doctrine. See Highland Sales Corp. v. Vance, 244 Ind. 20, 186 N.E.2d 682 (1962); People v. Pam, 38 Misc. 2d 296, 238 N.Y.S.2d 363 (N.Y. City Crim. Ct. 1963), aff'd, 43 Misc. 2d 357, 250 N.Y.S.2d 877 (Sup. Ct. 1964); State v. Gamble Skogmo, Inc., 144 N.W.2d 749 (N.D. 1966); Commonwealth v. Bauder, 14 Pa. D. \& C.2d 571 (Lehigh County), aff'd, 188 Pa. Super. 424, 145 A.2d 915 (1958). The Taylor case held that the police could discriminate among similar businesses provided that they did so in a way that could have been done by the legislature. On the other hand, the other cases held that the defendants had failed to prove that they had been discriminated against by being prosecuted while other similar businesses were allowed to remain open. Highland Sales Corp. v. Vance, 244 Ind. at 34, 186 N.E.2d at 689; People v. Pam, 38 Misc. 2d at 298, 238 N.Y.S.2d at 365; State v. Gamble Skogmo, Inc., 144 N.W.2d at 764-65; Commonwealth v. Bauder, 14 Pa. D. \& C.2d at $584,145 \mathrm{~A} .2 \mathrm{~d}$ at 922 . There were also indications that the businesses against which the statutes allegedly were not being enforced may have been within statutory exceptions. See Highland Sales Corp. v. Vance, 244 Ind. at 33, 186 N.E.2d at 688; People v. Pam, 38 Misc. 2d at 299, 238 N.Y.S.2d at 367; State v. Gamble Skogmo, Inc., 144 N.W.2d at 758-59; Commonwealth v. Bauder, 14 Pa. D. \& C.2d at 582-84, $145 \mathrm{~A} .2 \mathrm{~d}$ at 921.

Professor Arthur Bonfield has suggested that the Iowa Administrative Procedure Act, IOwA CODE $\S 17 \mathrm{~A}$ (1975), which he authored, may permit the enforcement agencies in Iowa to make distinctions along the lines suggested in Taylor. Bonfield, The Iowa Administrative Procedure Act: Background, Construction, Applicability, Public Access to Agency Law, The Rulemaking Process, 60 IowA L. Rev. 731, 787-89 (1975). It is not clear whether he is including the police within his description, although the act encompasses "all state agencies." Id. 732. More importantly, it is not clear to what extent the Act is inconsistent with my position. For example, it provides that an agency need not publicize allocation decisions if deterrence would thereby suffer. $I d$. 788-89. Thus, it does not necessarily provide for the administrative repeal of statutes.

${ }^{217}$ This does not mean that the police cannot ignore a particular complaint, of burglary for example, if, because of limited resources, they are faced with the choice of either investigating that particular complaint or conducting a more serious murder investigation. The point is that the police cannot choose, as a policy matter, to ignore all burglary complaints.

${ }^{218}$ See note 5 supra. 
when probable cause exists, will not be "lawless." For example, an officer faced with a situation in which a justified arrest would provoke a riot would surely be excused from making the arrest in any jurisdiction with a choice of evils statute based upon section 3.02 of the Model Penal Code. ${ }^{219}$ A similar result would probably be achieved via the common law even in those states without such a statute. ${ }^{220}$ Moreover, even a patrolman who desires to enforce fully a criminal statute cannot make an arrest without first concluding that there is probable cause to believe the suspect has broken the law. ${ }^{221}$ Although the officer in his zeal to do his duty may decide to resolve all factual issues in favor of concluding that probable cause exists, he still must decide whether or not there is a factual issue to be resolved; in an unclear factual situation this will naturally involve the exercise of discretion. ${ }^{222}$

In the above situations the discretion exercised by the police officer merely involves interpretation and application of the

\section{${ }^{219}$ E.g., N.Y. PENAL LAW \& 35.05(2) (McKinney 1975).}

${ }^{220}$ See generally W. LaFave \& A. ScotT, Handbook on Criminal Law 381-89 (1972).

${ }^{221}$ Gerstein v, Pugh, 420 U.S. 103 (1975); Beck v. Ohio, 379 U.S. 89, 91 (1964).

222 For an interesting discussion of the police determination that a crime has been committed, see Comment, Police Discretion and the Judgment that a Crime has been Committed-Rape in Philadelphia, 117 U. PA. L. REv. 277 (1968).

Very much related to the problem of evaluating factual nuances is the problem of interpreting and applying ambiguous statutes; both involve deciding whether or not a particular statute embraces observed or reported activity. See H. LASSwELl, THE Decision Process (1956). Cf. Baxter, Choice of Law and the Federal System, 16 STAN. L. Rev. 1, 2-3 (1963). This ambiguity stems partly from the imprecision of the English language, see Remington \& Rosenblum, supra note 3 , at 494 , and partly from the deliberate choice or inadvertant oversight of the legislature. See W. LAFAvE, supra note 6, at 84-87. Another related problem arises from statutes that the legislature may not intend to be taken at face value. See generally id. 83-101; Goldstein, supra note 12, at 1136; Israel, The Process of Penal Law Reform-A Look at the Proposed Michigan Revised Criminal Code, 14 WAYNE L. REv. 772, 813-16 (1968); Kadish, supra note 175, at 909-10; Remington \& Rosenblum, supra note 3 , at 489-93.

There is disagreement over the appropriate response of the police to an ambiguous statute. W. LAFAVE, supra note 6 , at $85 \mathrm{nn} .3,4$. In my opinion the police should attempt to get a definitive interpretation. Given the nature of the institutions we are dealing with, this interpretation would be most readily obtained from the prosecutor. Id. 85-86. A more satisfactory resolution would be to obtain a ruling from the State Attorney General, if he is empowered to issue it, or to request a declaratory ruling from a court of competent jurisdiction. The police themselves should not interpret statutes directly, except as necessary to apply them. When interpretation proceeds beyond the point of obvious necessity, it begins to impinge too far upon the prerogatives of other branches of government. For discussions of the relationship between an agency's interpretation of statutes and review of that interpretation by the courts, see Frankfurter, Some Reflections on the Reading of Statutes, 47 CoLUM. L. REv. 527, 543 (1947). See also Louisville \& N.R.R. v. United States, 282 U.S. 740, 757 (1931); Boyd v. United States, 116 U.S. 616, 622 (1886). 
legislative will to a particular situation; the officer is not acting upon his determination of what the law should be. Insofar as laws cannot be written to accommodate every conceivable set of circumstances, such discretion will always be a necessary part of our law enforcement system. When an unanticipated situation arises calling for a quick decision by the officer, it may be "lawful" for the officer to decide that the legislature could not have intended the statute to apply in that particular circumstance.

On the other hand, the type of police discretion of particular concern in this Article involves the choice of whether or not to enforce a criminal statute when the statute was clearly intended to be applied. In such a situation the police officer should arrest the offender regardless of his personal beliefs regarding the wisdom and morality of the statute. As Professor Goldstein has stated:

The ultimate answer is that the police should not be delegated discretion not to invoke the criminal law .... [T] he police should operate in an atmosphere which exhorts and commands them to invoke impartially all criminal laws within the bounds of full enforcement. If a criminal law is ill-advised, poorly defined, or too costly to enforce, efforts by the police to achieve full enforcement should generate pressures for legislative action. ${ }^{223}$

I realize, of course, that a command "to invoke impartially all criminal laws" will not be heeded in its entirety. ${ }^{224}$ Moreover, I am deeply troubled by the difficult choice faced by a police officer who feels that the circumstances are so compelling that he cannot, in good conscience, arrest a suspected offender. ${ }^{225}$ Nonetheless, I cannot free myself from the inhibiting realization that I am but one member of a free and self-governing society. If a sufficient number of my fellow citizens shared my view as to wisdom, we could incorporate it into our law. The fact that an

${ }^{223}$ Goldstein, supra note 4, at 586-87. See also Givelber, supra note 28, at 96 .

224 See, e.g., Police Discretion, supra note 14, at 88-90 (the story of Patrolman X). See also Goldstein, supra note 4, at 561 ("Even if there were 'enough police' . . pressures from within and without the department, which is after all a human institution, may force the police to invoke the criminal process selectively.").

For discussions of the use of mandamus to compel the police to enforce a statute, see W. LAFAvE, supra note 6, at 160-61; Goldstein, supra note 4, at 592-94; Note, Discriminatory Law Enforcement and Equal Protection from the Law, 59 YALE L.J. 354 (1950). See also Note, The Federal Injunction As a Remedy for Unconstitutional Police Conduct, 78 YAle L.J. 143 (1968).

${ }^{225}$ Cf. C. CurTIS, It's Your LAw 95 (1954), quoted in Kamisar, Some Non-Religious Views Againist Proposed "Mercy-Killing" Legislation, 42 MiNN. L. REv. 969, 971 (1958). 
officer must choose in any particular case between doing what he or I believe is right and enforcing the law merely demonstrates the large area within which reasonable men may disagree. Thus, the only answer to the officer's dilemma is that he must choose between enforcing the law when he believes it is unwise or unjust and accepting the penalty if discovered refusing to do so.226 Imposing sanctions on such behavior will, hopefully, inhibit a police officer from too often or too casually arrogating to himself the power to determine the appropriateness of a particular penal statute.

Some doubtless will find the suggestions I have advanced to control police discretion to be little more than palliatives. In one sense I share that view. I suffer from no delusions that my suggestions, if implemented, would magically eliminate discretionary law enforcement. This is because discretionary law enforcement is not solely, nor even mainly, the result of police departments that lack the will, the resources, or the organization to enforce fully the criminal law. No, the cause lies elsewherein legislatures that overuse the criminal sanction, in a citizenry that insists upon using the criminal law and its institutions for purposes beyond their competences, and in academics who fail to explicate what those limits of institutional competence are. The solution to the problem of police discretion, in other words, lies elsewhere than in the police themselves. This is not to say that we should abandon attempts to restrict lawless action or inaction by the police, but it is to say that lawless action should not be dealt with through further lawless action, especially when that further lawless action is not likely to achieve its goals. Substantive rulemaking approaches the problem of police discretion

${ }^{226}$ The full enforcement statutes generally penalize an officer's dereliction of duty. See statutes cited notes 48-50 supra.

It is at this point that I apparently disagree with Professors Kadish and Kadish, who take the position that certain departures from legal rules are justified within the context of a legal system, and who consequently would not punish an officer who makes such a departure. See M. Kadish \& S. Kadish, Discretion to Disobey (1973). Although I will not attempt an extended analysis of this complex and thoughtful book, I do wish to point out that the divergence between us may not be that great. The authors note that: "If there is to be legitimation at all . . . the system must establish and make available to the agent who proposes to depart from a rule some body of policies, principles, and ends in virtue of which the departure may be justified." Id. 67. If this body of principles justifying a rule departure is provided by the legislature, then an officer who follows them has not departed from a legal rule at all; in fact the opposite is true. Thus, my only disagreement with the Kadishes may be over the source of this body of principles. See also Christie, Lawful Departures from Legal Rules: "Jury Nullification" and Legitimated Disobedience, 62 CAL. L. REv. 1289, 1300 (1974). 
as if the police existed in a vacuum rather than in a complex society. Accordingly, it takes no account of the wider ramifications implicit within it.

To be sure, we should do what we can with the police. We should insure that resources are wisely allocated, and we should attempt to make the full enforcement legislation accord with reality as far as possible. Beyond this, we should keep in mind the limits of the effective use of the criminal law, as well as the inherent limitations of law enforcement agencies. More importantly, however, we should hesitate before we too quickly sacrifice principle to a beguiling expedient, lest we discover that we have given away much in return for very little. 